National Stream Quality Accounting Network National Water-Quality Assessment Program

\title{
Streamflow Characterization and Summary of Water-Quality Data Collection during the Mississippi River Flood, April through July 2011
}

Open File Report 2013-1106

U.S. Department of the Interior U.S. Geological Survey 
Cover. Aerial view of the confluence of Steele Bayou with the Yazoo River looking southwest during the 2011 Mississippi River flood. The picture shows backwater flooding of the Yazoo River from the Mississippi River which is located in the upper foreground.

Photo by Scott Koestler. 


\section{Streamflow Characterization and Summary of Water-Quality Data Collection during the Mississippi River Flood, April through July 2011}

By Heather L. Welch and Kimberlee K. Barnes

National Stream Quality Accounting Network

National Water-Quality Assessment Program

Open-File Report 2013-1106 


\title{
U.S. Department of the Interior SALLY JEWELL, Secretary
}

\section{U.S. Geological Survey Suzette M. Kimball, Acting Director}

\author{
U.S. Geological Survey, Reston, Virginia: 2013
}

For more information on the USGS - the Federal source for science about the Earth, its natural and living resources, natural hazards, and the environment, visit http://www.usgs.gov or call 1-888-ASK-USGS.

For an overview of USGS information products, including maps, imagery, and publications, visit http://www.usgs.gov/pubprod

To order this and other USGS information products, visit http://store.usgs.gov

Any use of trade, firm, or product names is for descriptive purposes only and does not imply endorsement by the U.S. Government.

Although this information product, for the most part, is in the public domain, it also may contain copyrighted materials as noted in the text. Permission to reproduce copyrighted items must be secured from the copyright owner.

Suggested citation:

Welch, H.L., and Barnes, K.K., 2013, Streamflow characterization and summary of water-quality data collection during the Mississippi River flood, April through July 2011: U.S. Geological Survey Open-File Report 2013-1106, 29 p., http://pubs.usgs.gov/of/2013/1106/. 


\section{Contents}

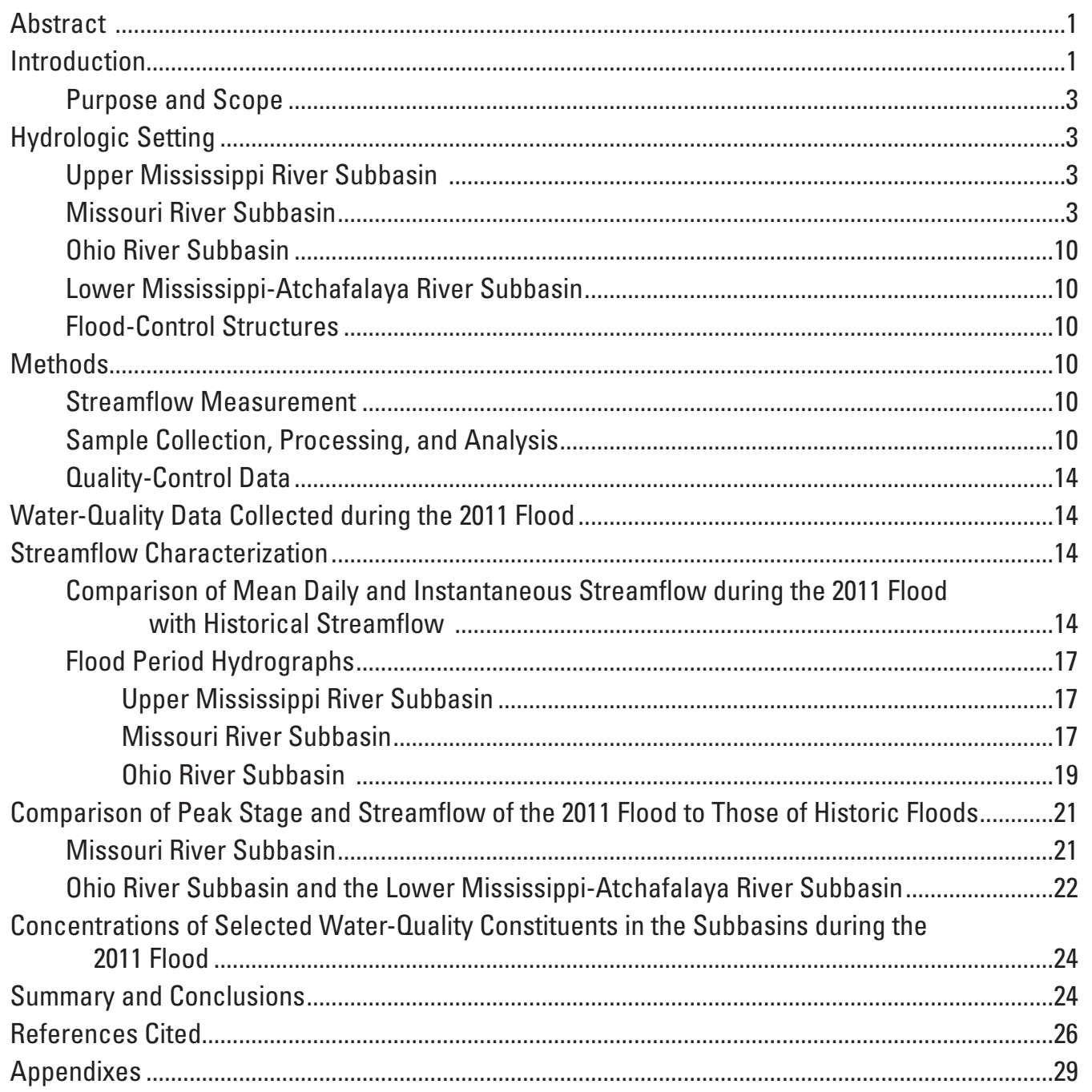

\section{Figures}

1. Map showing the extent of the Mississippi River Basin and Subbasins ...........................2

2. Map showing the upper Mississippi River Subbasin and sites sampled

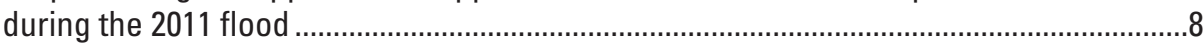

3. Map showing the Missouri River Subbasin and sites sampled during the

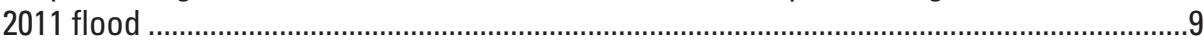

4. Map showing the Ohio River Subbasin and sites sampled during the 2011 flood

5. Map showing the lower Mississippi-Atchafalaya River Subbasin and sites sampled during the 2011 flood

6. Map showing the location of water-quality samples collected in the Birds Point-New Madrid Floodway and the Morganza Floodway and the Bonnet Carré Spillway during the 2011 flood 
7. Box plots comparing historical instantaneous streamflow with instantaneous streamflow measured during the 2011 flood at selected sites in the upper Mississippi River Subbasin, the Missouri River Subbasin, the Ohio River

Subbasin, and the lower Mississippi-Atchafalaya River Subbasin ...

8. Hydrograph showing mean daily streamflow in the upper Mississippi River Subbasin from March through July 2011 and the instantaneous streamflow at the time of water-quality data collection

9. Hydrograph showing mean daily streamflow in the Missouri River Subbasin from March through July 2011 and the instantaneous streamflow at the time of water-quality data collection

10. Hydrograph showing mean daily streamflow in the Ohio River Subbasin from March through July 2011 and the instantaneous streamflow at the time of water-quality data collection.

11 Hydrograph showing the contribution of streamflow to the lower Mississippi-Atchafalaya River Subbasin from the upper Mississippi River and Ohio River Subbasins

12. Hydrograph showing mean daily streamflow at sites on the main stem in the lower Mississippi-Atchafalaya River Subbasin from March through July 2011 and the instantaneous streamflow at the time of water-quality data collection.

13. Hydrograph showing mean daily streamflow at sites on the Atchafalaya River in the lower Mississippi-Atchafalaya River Subbasin from March through July 2011 and the instantaneous streamflow at the time of water-quality data collection.

14. Photograph showing how U.S. Army Corps of Engineers documents the height of all major floods of the Mississippi River on the levee wall at Vicksburg, Mississippi .

\section{Tables}

1. U.S. Geological Survey stations sampled for water-quality during the 2011 Mississippi River flood.

2. U.S. Geological Survey streamflow station names, station numbers, drainage basin areas, and minimum, maximum, and median streamflow data for April through July 2011 at selected sites in the upper Mississippi River Subbasin, the Missouri River Subbasin, the Ohio River Subbasin, and the lower Mississippi-Atchafalaya River Subbasin.

3. Maximum stages and streamflows for 2011 and selected largest-flood years at select U.S. Geological Survey streamflow stations in the Mississippi River Basin

4. Concentrations of selected constituents measured in each of the four subbasins during the 2011 Mississippi River flood, April through July. 


\section{Conversion Factors}

Inch/Pound to SI

\begin{tabular}{lcl}
\hline \multicolumn{1}{c}{ Multiply } & \multicolumn{1}{c}{ By } & \multicolumn{1}{c}{ To obtain } \\
\hline inch (in.) & Length & \\
inch (in.) & 2.54 & centimeter $(\mathrm{cm})$ \\
foot (ft) & 25.4 & millimeter $(\mathrm{mm})$ \\
mile (mi) & 0.3048 & meter $(\mathrm{m})$ \\
\hline & 1.609 & kilometer $(\mathrm{km})$ \\
\hline square mile $\left(\mathrm{mi}^{2}\right)$ & Area & \\
\hline & 2.590 & square kilometer $\left(\mathrm{km}^{2}\right)$ \\
\hline cubic foot $\left(\mathrm{ft}^{3}\right)$ & Volume & \\
\hline & 0.02832 & cubic meter $\left(\mathrm{m}^{3}\right)$ \\
\hline cubic foot per second $\left(\mathrm{ft}^{3} / \mathrm{s}\right)$ & 0.02832 & \\
\hline & Mlow rate & cubic meter per second $\left(\mathrm{m}^{3} / \mathrm{s}\right)$ \\
\hline ton per year (ton $/ \mathrm{yr})$ & 0.9072 & metric ton per year \\
\hline
\end{tabular}

Temperature in degrees Celsius $\left({ }^{\circ} \mathrm{C}\right)$ may be converted to degrees Fahrenheit $\left({ }^{\circ} \mathrm{F}\right)$ as follows:

${ }^{\circ} \mathrm{F}=\left(1.8 \mathrm{x}^{\circ} \mathrm{C}\right)+32$

Temperature in degrees Fahrenheit ()F) may be converted to degrees Celsius $\left({ }^{\circ} \mathrm{C}\right)$ as follows: ${ }^{\circ} \mathrm{C}=\left({ }^{\circ} \mathrm{F}-32\right) / 1.8$

The distance above a vertical datum is referenced to the National Geodetic Vertical Datum of 1929 (NGVD 29).

Horizontal coordinate information is referenced to the North American Datum of 1983 (NAD 83).

Specific conductance is given in microsiemens per centimeter at 25 degrees Celsius

$\left(\mu \mathrm{S} / \mathrm{cm}\right.$ at $\left.25^{\circ} \mathrm{C}\right)$

\section{Abbreviations}

GC-FID gas chromatograph with a flame ionization detector

NASQAN National Stream Quality Accounting Network

NAWQA National Water Quality Assessment

USGS U.S. Geological Survey 



\title{
Streamflow Characterization and Summary of Water- Quality Data Collection during the Mississippi River Flood, April through July 2011
}

\author{
By Heather L. Welch and Kimberlee K. Barnes
}

\section{Abstract}

From April through July 2011, the U.S. Geological Survey collected surface-water samples from 69 waterquality stations and 3 flood-control structures in 4 major subbasins of the Mississippi River Basin to characterize the water quality during the 2011 Mississippi River flood. Most stations were sampled at least monthly for field parameters, suspended sediment, nutrients, and selected pesticides.

Samples were collected at daily to biweekly frequencies at selected sites in the case of suspended sediment. Hydrocarbon analysis was performed on samples collected at two sites in the Atchafalaya River Basin to assess the waterquality implications of opening the Morganza Floodway. Water-quality samples obtained during the flood period were collected at flows well above normal streamflow conditions at the majority of the stations throughout the Mississippi River Basin and its subbasins.

Heavy rainfall and snowmelt resulted in high streamflow in the Mississippi River Basin from April through July 2011. The Ohio River Subbasin contributed to most of the flow in the lower Mississippi-Atchafalaya River Subbasin during the months of April and May because of widespread rainfall, whereas snowmelt and precipitation from the Missouri River Subbasin and the upper Mississippi River Subbasin contributed to most of the flow in the lower Mississippi-Atchafalaya River Subbasin during June and July. Peak streamflows from the 2011 flood were higher than peak streamflow during previous historic floods at most of the selected streamgages in the Mississippi River Basin. In the Missouri River Subbasin, the volume of water moved during the 1952 flood was greater than the amount moved during the 2011 flood.

Median concentrations of suspended sediment and total phosphorus were higher in the Missouri River Subbasin during the flood when compared to the other three subbasins. Surface water in the upper Mississippi River Subbasin contained higher median concentrations of total nitrogen, nitrate, orthophosphate, and atrazine during the flood period.

\section{Introduction}

The Mississippi River Basin drains about 41 percent of the conterminous United States including all or part of 31 states, as well as two Canadian provinces. The Mississippi River is the fourth longest river in the world and its river basin is the largest in North America (fig. 1). The four major Mississippi River subbasins are the upper Mississippi, the Missouri, the Ohio, and the lower Mississippi-Atchafalaya. The majority of corn, soybeans, wheat, cattle, hogs, and to a lesser extent, cotton and rice produced in the United States originates from agricultural regions within the Mississippi River Basin (Coupe and Goolsby, 1999). To optimize agricultural production, pesticides and fertilizers are applied to the land surface. These agricultural chemicals, along with sediment from agricultural fields, can be transported by local streams to the Mississippi River and eventually to the Gulf of Mexico.

From December 2010 through July 2011, the northern two-thirds of the United States experienced mostly wet conditions, while the southern United States experienced mostly dry conditions (Vining and others, 2013). Portions of the Ohio River Subbasin received nearly 20 inches of rain in April alone, which is about half of the annual average precipitation (Vining and others, 2013). The precipitation combined with melting of record snowfall in the Missouri River Subbasin resulted in extensive flooding of the Mississippi River Basin from April through July 2011, hereafter referred to as the "2011 flood" or simply "the flood" (Vining and others, 2013).

Because floods, by definition, affect lands not typically inundated by water, chemicals and sediment associated with the landscape can be carried by floodwater great distances from their source area. As a result, there is substantial deposition of sediment, sediment-associated constituents, and other chemicals on floodplains. In addition, soil saturation during periods of heavy precipitation leads to increased overland flow, limiting the processing of chemicals such as nutrients and pesticides in the soil profile. Therefore, the extensive flooding in the Mississippi River Basin from April through July 2011 likely resulted in large amounts of chemicals moving downstream to receiving surface-water bodies, such as the Gulf of Mexico. 


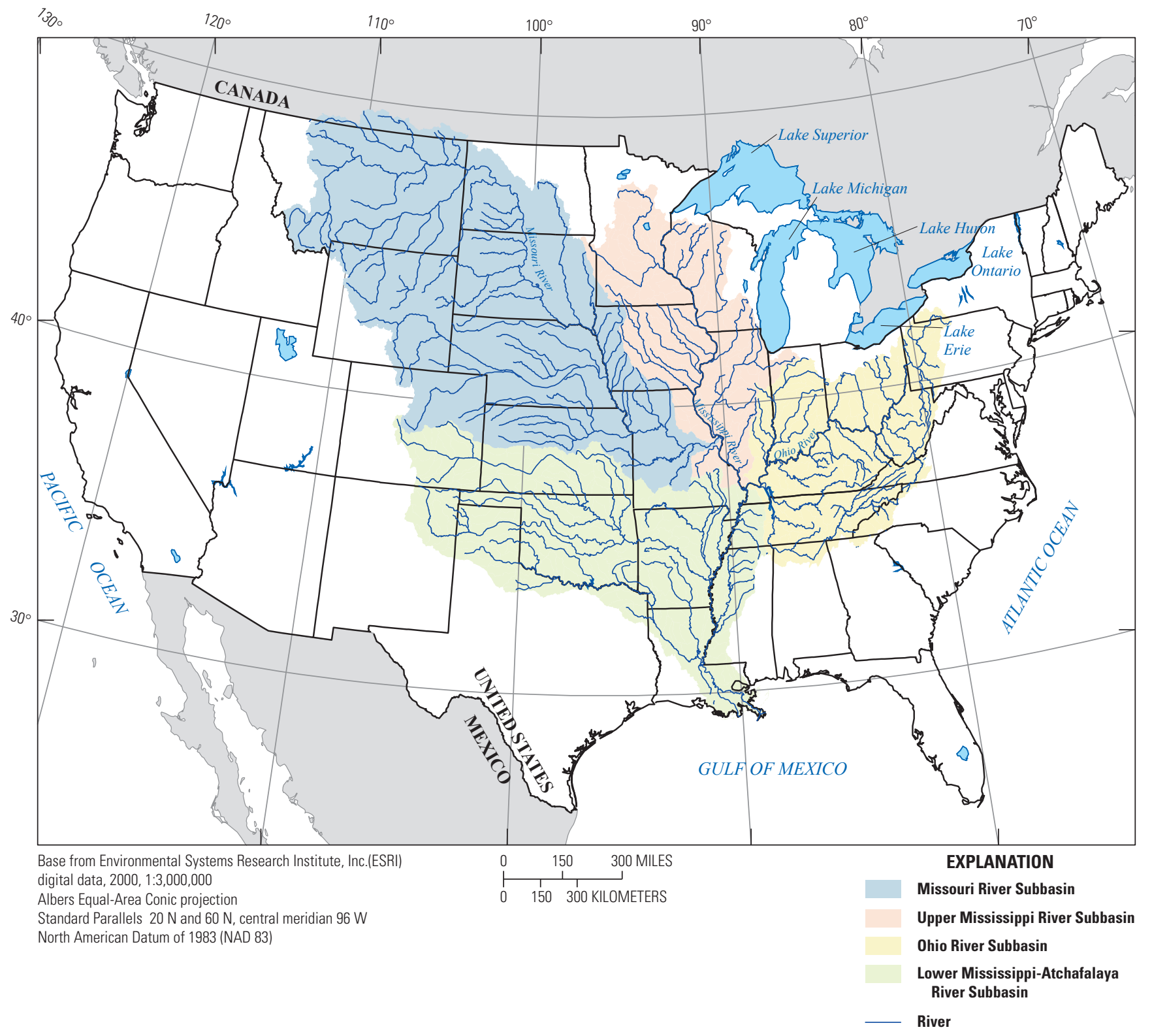

Figure 1. Extent of the Mississippi River Basin and Subbasins.

The U.S. Geological Survey (USGS) has been monitoring streamflow and water quality in the Mississippi River Basin for decades as part of several national programs. The National Stream Quality Accounting Network (NASQAN) was established in 1973 to provide long-term water-quality monitoring for river systems throughout the United States. Since October 2007, the focus of NASQAN has been to document concentrations and loads of selected constituents delivered by major rivers to the coastal waters of the United States and selected inland subbasins to determine the sources and relative yields of those constituents within these subbasins. Twenty NASQAN sites and one National Monitoring Network site (operated by the USGS in partnership with the National Water Quality Monitoring Council) compose the water-quality and streamflow network in the Mississippi River Basin. Since the 1990s, the USGS National Water Quality Assessment
(NAWQA) Program has been collecting samples to identify water-quality conditions in the Nation's major streams and rivers. Forty surface-water sites are sampled as part of the NAWQA Program in the Mississippi River Basin. Long-term water-quality and streamflow monitoring sites, such as those operated by the USGS within the NASQAN and NAWQA Programs, allows for comparing and contrasting chemical and sediment fluxes and concentrations at times of normal and unexpected stream conditions.

In 2011, the USGS utilized the existing NASQAN/ NAWQA network and stations funded through various cooperative agreements to assess the effects of the 2011 flood on water quality in the Mississippi River Basin. Additional sites were added above and below the major flood-control structures to supplement the network and to help determine whether opening of the structures had any effect on water 
quality in the lower Mississippi-Atchafalaya River Subbasin. The information collected during the 2011 flood will allow the USGS to decide whether data collection methods during the flood allowed for adequate characterization of the waterquality effects and will also help in future planning of data collection during high-flow events.

\section{Purpose and Scope}

The purposes of this report are to (1) document data collection methods that were used during the 2011 flood, including an analysis of the quality assurance/quality control data that were collected, (2) compare streamflow measured during the 2011 flood to that of past historic floods within the upper Mississippi River Subbasin, the Missouri River Subbasin, the Ohio River Subbasin, and the lower MississippiAtchafalaya River Subbasin, (3) document sites that were sampled during the flood, and (4) document all water-quality data collected during the flood. Water-quality data were collected and streamflow was measured by the USGS at 69 sites and 3 flood-control structures during the 2011 flood. Water-quality collection methods and the data published in this report provide a basis for subsequent investigations of the 2011 flood.

In this report, the site numbers specified in table 1 (shown later) are cited in subsequent discussions to aid the reader in locating site-specific information presented in the figures and tables.

\section{Hydrologic Setting}

The Mississippi River originates in Lake Itasca, Minnesota and extends southward over 2,300 miles through the central part of the United States to the Gulf of Mexico. The river and its tributaries drain part or all of 31 different states within a basin area covering approximately 1.24 million square miles $\left(\mathrm{mi}^{2}\right)$ (fig. 1); the size of the basin is only exceeded by those of the Amazon and Congo Rivers. The drainage area of the river has been subdivided into four parts in this report for ease of discussion: (1) the upper Mississippi River Subbasin, which is the part upstream from the confluence with the Ohio River, excluding the Missouri River Subbasin; (2) the Missouri River Subbasin; (3) the Ohio River Subbasin; and (4) the lower Mississippi-Atchafalaya River Subbasin, located downstream from the confluence of the upper Mississippi and Ohio Rivers and draining into the Gulf of Mexico (fig. 1). Half of the water discharged to the Gulf of Mexico is contributed by the Ohio River and its tributaries, which represent approximately one-sixth of the total area drained by the Mississippi River. In contrast, the Missouri River drains 43 percent of the Mississippi River Basin, but contributes only about 12 percent of the total streamflow to the Gulf of Mexico (Meade, 1995).

\section{Upper Mississippi River Subbasin}

The upper Mississippi River Subbasin covers approximately $190,000 \mathrm{mi}^{2}$ across parts of seven states in the upper Midwest (fig. 2). The river flows about 1,300 miles from its headwaters at Lake Itasca in northern Minnesota to its confluence with the Missouri River at St. Louis, Missouri. The upper Mississippi River is divided into two sections: the reach from the headwaters at Lake Itasca to Saint Anthony Falls in Minneapolis, Minnesota, and the navigable channel formed by a series of man-made lakes between Minneapolis and St. Louis, Missouri. Authorized by Congress and built mostly in the 1930s, these artificial lakes were created using a system of 29 locks and dams constructed to regulate water levels in the channel for commercial navigation. Major tributaries of the upper Mississippi River include the Wisconsin, Illinois, Iowa, and Missouri Rivers. Land use in the subbasin is predominantly (1) corn and soybean cropland and pasture, covering about 60 percent of the area; and (2) forest land, covering about 20 percent of the area (Homer and others, 2007).

\section{Missouri River Subbasin}

The largest watershed within the Mississippi River Basin is the Missouri River Subbasin, which encompasses parts of 10 states and two Canadian provinces (fig. 3). This subbasin drains approximately $529,000 \mathrm{mi}^{2}$ of the north-central United States. Land use in the basin is predominately agricultural, covering about 95 percent of the total area, with more than half of the area in pasture and range grassland devoted to grazing (U.S. Army Corps of Engineers, 2006).

Beginning in the Rocky Mountains near Three Forks, Montana, three streams form the headwaters of the Missouri River, which flows more than 2,500 miles east and south through the central prairies joining the Mississippi River north of St. Louis, Missouri. The Missouri River valley consists of highly erodible soils, and the river itself is well known for having a shifting channel bottom, high turbidity, and typically, two periods of very high flows each year. The first high-flow event typically occurs in the spring and is caused by snowmelt on the plains, the second occurs in June from snowmelt and summer rainstorms in the Rocky Mountains. Prior to human modification, sediment loads averaged about 250 million tons per year (ton/yr) at Hermann, Missouri (U.S. Army Corps of Engineers, 2006). As part of the Flood Control Act of 1944, modification projects along the Missouri River began in the 1940s and 1950s, effectively dividing the river into three parts, approximately equal in length. The upper part contains six large dams creating the following reservoirs: Fort Peck Lake, Lake Sakakawea, Lake Oahe, Lake Sharpe, Lake Francis Case, and Lewis and Clark Lake. The middle part consists of free-flowing reaches, and the lower part, below Sioux City, Iowa, is channelized (Stone, date unknown). 
Table 1. U.S. Geological Survey stations sampled for water-quality during the 2011 Mississippi River flood.

[Site locations are shown in figures 2-6. USGS, U.S. Geological Survey]

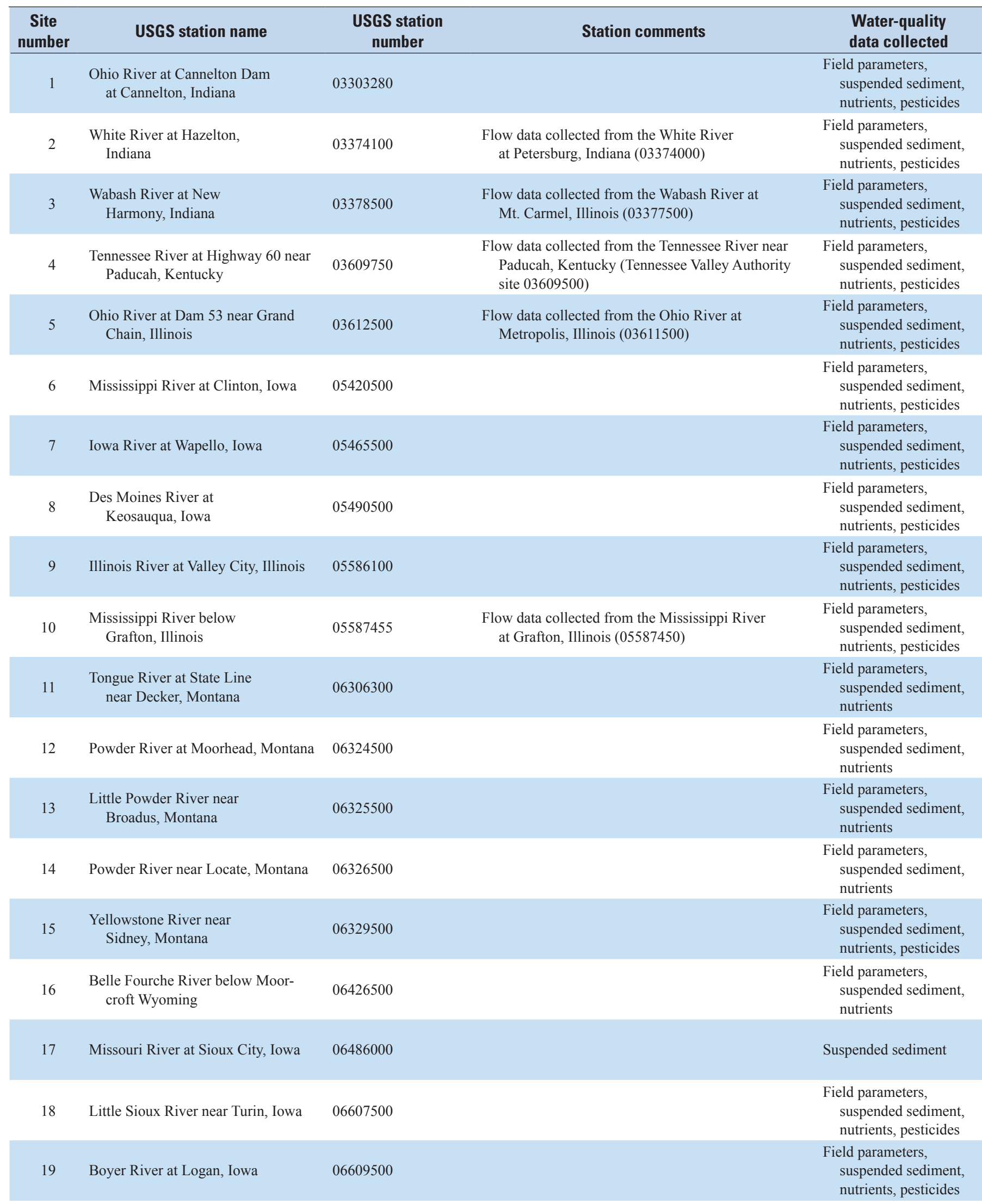


Table 1. U.S. Geological Survey stations sampled for water-quality during the 2011 Mississippi River flood.—Continued

[Site locations are shown in figures 2-6. USGS, U.S. Geological Survey]

\begin{tabular}{|c|c|c|c|c|}
\hline $\begin{array}{c}\text { Site } \\
\text { number }\end{array}$ & USGS station name & $\begin{array}{c}\text { USGS station } \\
\text { number }\end{array}$ & Station comments & $\begin{array}{l}\text { Water-quality } \\
\text { data collected }\end{array}$ \\
\hline 20 & $\begin{array}{l}\text { Missouri River at Omaha, } \\
\text { Nebraska }\end{array}$ & 06610000 & & $\begin{array}{l}\text { Field parameters, } \\
\text { suspended sediment, } \\
\text { nutrients, pesticides }\end{array}$ \\
\hline 21 & $\begin{array}{l}\text { Cherry Creek at Denver, } \\
\text { Colorado (urban Denver) }\end{array}$ & 06713500 & & $\begin{array}{l}\text { Field parameters, } \\
\text { suspended sediment, } \\
\text { nutrients, pesticides }\end{array}$ \\
\hline 23 & $\begin{array}{l}\text { Big Thompson River at I-25 } \\
\text { near Loveland, Colorado } \\
\text { (urban influence) }\end{array}$ & 06741530 & & $\begin{array}{l}\text { Field parameters, } \\
\text { suspended sediment, } \\
\text { nutrients }\end{array}$ \\
\hline 24 & $\begin{array}{l}\text { Elkhorn River at Waterloo, } \\
\text { Nebraska }\end{array}$ & 06800500 & & $\begin{array}{l}\text { Field parameters, } \\
\text { suspended sediment, } \\
\text { nutrients, pesticides }\end{array}$ \\
\hline 26 & $\begin{array}{l}\text { Salt Creek near Ashland, } \\
\text { Nebraska (downstream } \\
\text { of Lincoln, Nebraska) }\end{array}$ & 06805000 & & $\begin{array}{l}\text { Field parameters, } \\
\text { suspended sediment, } \\
\text { nutrients }\end{array}$ \\
\hline 27 & $\begin{array}{l}\text { Platte River at Louisville, } \\
\text { Nebraska }\end{array}$ & 06805500 & & $\begin{array}{l}\text { Field parameters, } \\
\text { suspended sediment, } \\
\text { nutrients, pesticides }\end{array}$ \\
\hline 28 & $\begin{array}{l}\text { Nishnabotna River above } \\
\text { Hamburg, Iowa }\end{array}$ & 06810000 & & $\begin{array}{l}\text { Field parameters, } \\
\text { suspended sediment, } \\
\text { nutrients, pesticides }\end{array}$ \\
\hline 29 & $\begin{array}{l}\text { Missouri River at St. Joseph, } \\
\text { Missouri }\end{array}$ & 06818000 & & $\begin{array}{l}\text { Field parameters, } \\
\text { suspended sediment, } \\
\text { nutrients }\end{array}$ \\
\hline 32 & $\begin{array}{l}\text { Indian Creek at State Line } \\
\text { Road Leawood, Kansas } \\
\quad \text { (urban Kansas City) }\end{array}$ & 06893390 & & $\begin{array}{l}\text { Field parameters, } \\
\text { suspended sediment, } \\
\text { nutrients, pesticides }\end{array}$ \\
\hline 33 & $\begin{array}{l}\text { Rock Creek at Kentucky Road } \\
\text { in Independence, Missouri }\end{array}$ & 06893620 & & $\begin{array}{l}\text { Field parameters, } \\
\text { suspended sediment, } \\
\text { nutrients }\end{array}$ \\
\hline 34 & $\begin{array}{l}\text { Little Blue River at Lees } \\
\text { Summit Road in } \\
\text { Independence, Missouri }\end{array}$ & 06893820 & & $\begin{array}{l}\text { Field parameters, } \\
\text { suspended sediment, } \\
\text { nutrients }\end{array}$ \\
\hline 35 & $\begin{array}{l}\text { Adair Creek at Independence, } \\
\text { Missouri }\end{array}$ & 06893830 & & $\begin{array}{l}\text { Field parameters, } \\
\text { suspended sediment, } \\
\text { nutrients }\end{array}$ \\
\hline 36 & $\begin{array}{l}\text { East Fork Little Blue River near } \\
\text { Blue Springs, Missouri }\end{array}$ & 06893890 & & $\begin{array}{l}\text { Field parameters, } \\
\text { suspended sediment, } \\
\text { nutrients }\end{array}$ \\
\hline 37 & $\begin{array}{l}\text { Spring Branch Creek at Holke Road } \\
\text { in Independence, } \\
\text { Missouri }\end{array}$ & 06893970 & & $\begin{array}{l}\text { Field parameters, } \\
\text { suspended sediment, } \\
\text { nutrients }\end{array}$ \\
\hline
\end{tabular}


Table 1. U.S. Geological Survey stations sampled for water-quality during the 2011 Mississippi River flood.—Continued

[Site locations are shown in figures 2-6. USGS, U.S. Geological Survey]

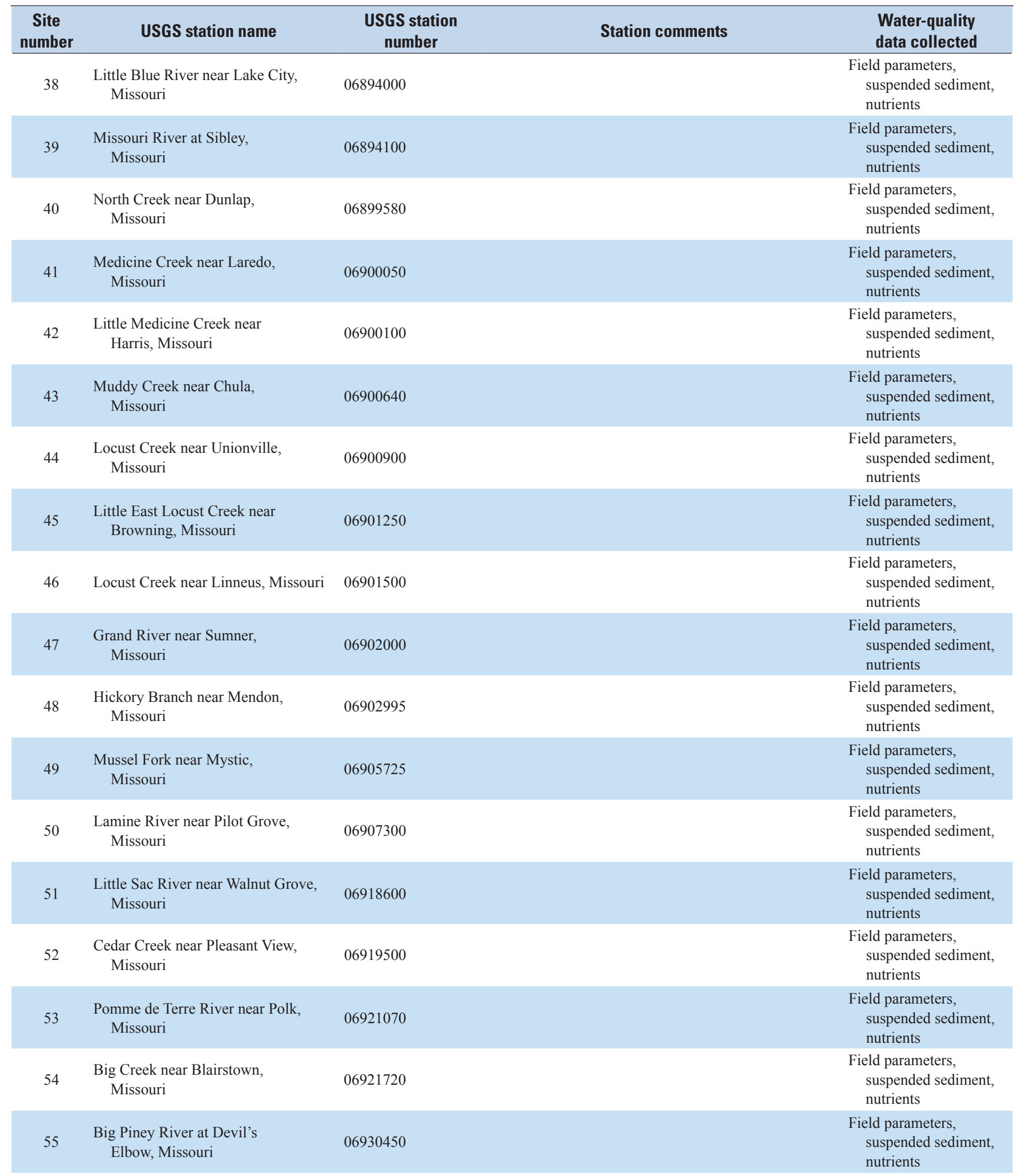


Table 1. U.S. Geological Survey stations sampled for water-quality during the 2011 Mississippi River flood.—Continued

[Site locations are shown in figures 2-6. USGS, U.S. Geological Survey]

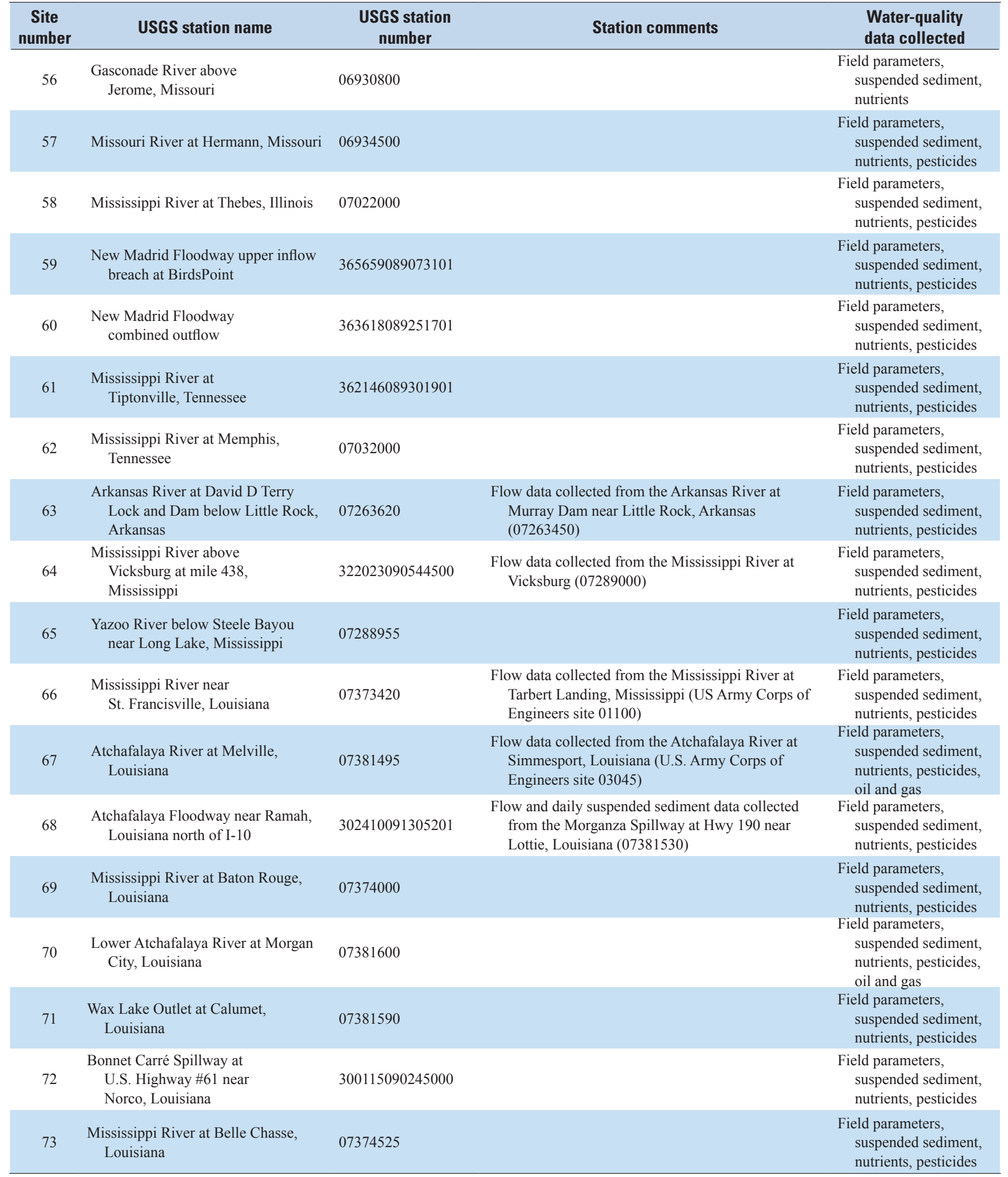




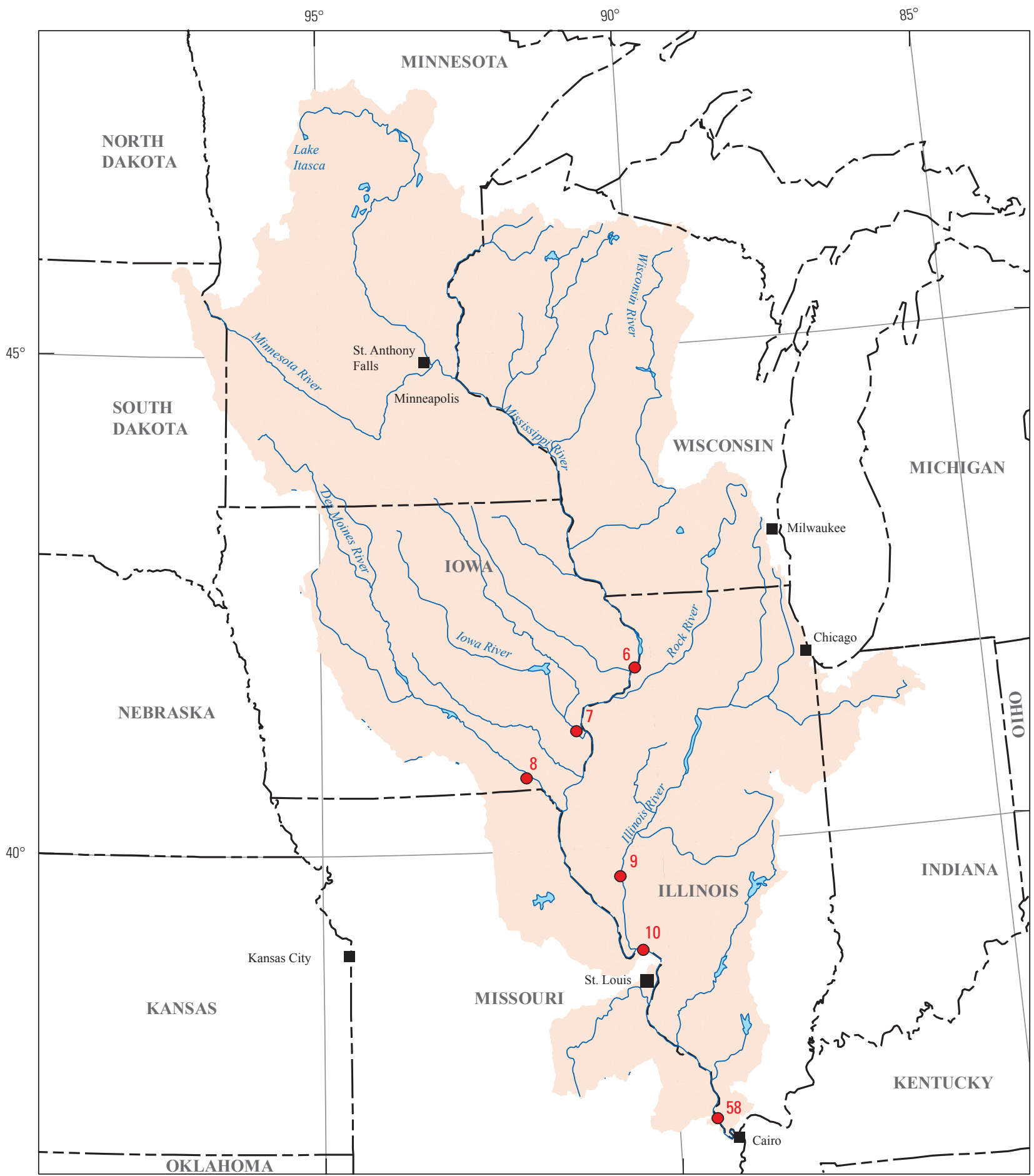

Base from Environmental Systems Research Institute, Inc.(ESRI) digital data, 2000, 1:3,000,000

Albers Equal-Area Conic projection

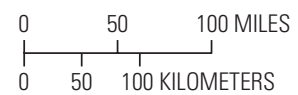

EXPLANATION

Standard Parallels $20 \mathrm{~N}$ and $60 \mathrm{~N}$, central meridian $96 \mathrm{~W}$

North American Datum of 1983 (NAD 83)

Upper Mississippi River Subbasin

USGS water-quality sampling site and identifier shown in table 1

Figure 2. Upper Mississippi River Subbasin and sites sampled during the 2011 flood. 


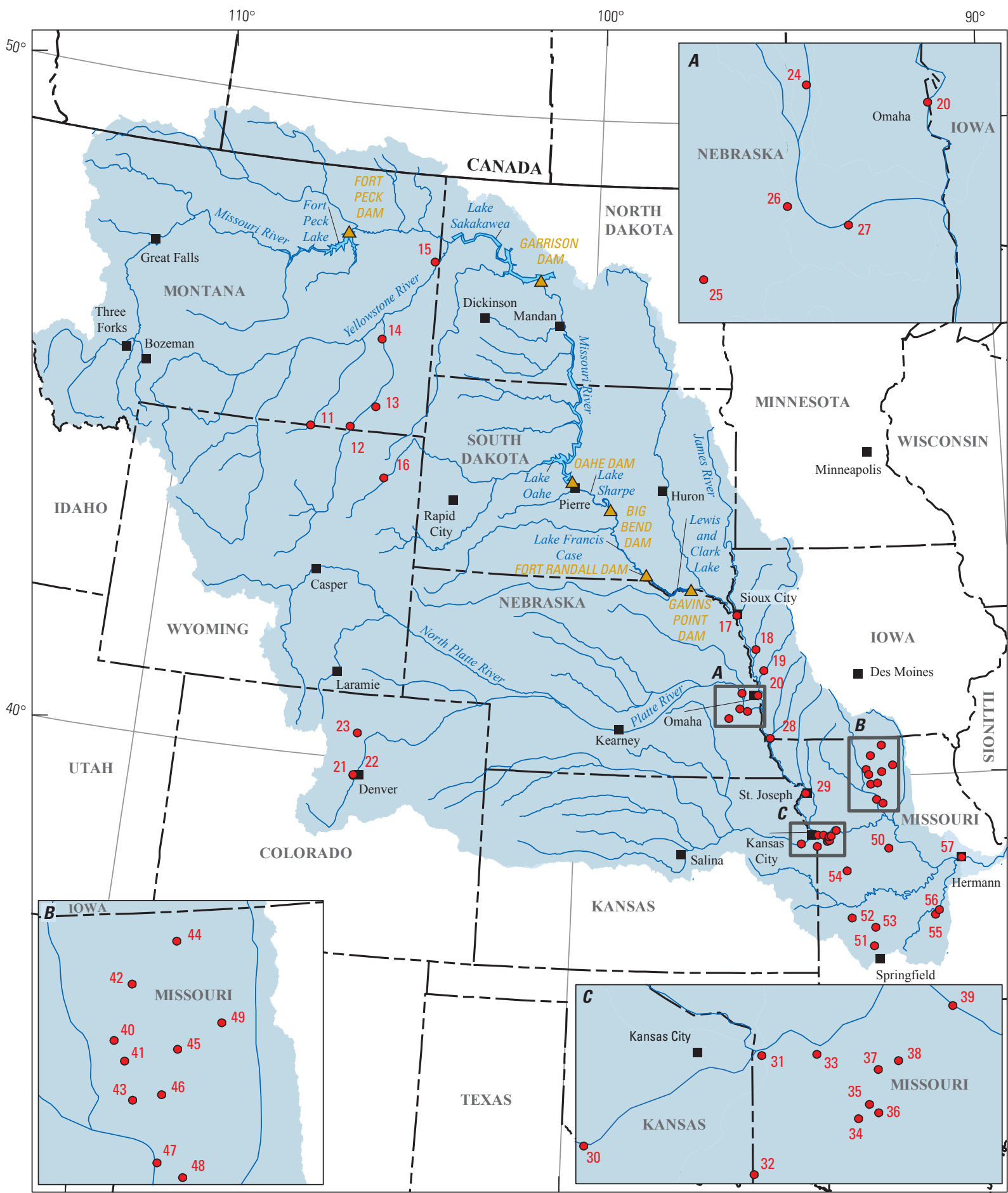

Base from Environmental Systems Research Institute, Inc.(ESRI) digital data, 2000, 1:3,000,000

Albers Equal-Area Conic projection

Standard Parallels $20 \mathrm{~N}$ and $60 \mathrm{~N}$, central meridian $96 \mathrm{~W}$ North American Datum of 1983 (NAD 83)

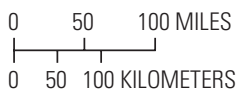

$0 \quad 50100$ KILOMETERS
EXPLANATION

Missouri River Subbasin

USGS water-quality sampling site and identifier shown in table 1

$\triangle \quad$ Dam and identifier

Figure 3. Missouri River Subbasin and sites sampled during the 2011 flood. 


\section{Ohio River Subbasin}

The Ohio River is located in the Eastern United States and is approximately 981 miles long. The river is formed by the confluence of the Allegheny and Monongahela Rivers in Pittsburgh, Pennsylvania, and joins the Mississippi River near the city of Cairo, Illinois (fig. 4). The Ohio River Subbasin encompasses about 190,000 $\mathrm{mi}^{2}$ across 15 states and is the largest tributary, by volume, of the Mississippi River. A series of 60 active navigation locks and dams have deepened the naturally shallow river for commercial navigation. Major tributaries include the Tennessee, Cumberland, Wabash, and Kanawha Rivers. Although almost 10 percent of the U.S. population lives within the basin, land use in the basin is predominately forest land, covering about 51 percent of the area and agriculture covering about 35 percent of the area (U.S. Army Corps of Engineers, 2009).

\section{Lower Mississippi-Atchafalaya River Subbasin}

The lower Mississippi-Atchafalaya River Subbasin drains all or part of 11 different states downstream from the confluence of the upper Mississippi and the Ohio Rivers (fig. 5). Parts of the lower Mississippi-Atchafalaya River Subbasin drain streams located in the Mississippi Alluvial Plain, which is relatively flat and contains rich, productive soils used extensively for agriculture. The lower Mississippi-Atchafalaya River Subbasin also receives inflow from streams located in rangeland, urban areas, and mountainous regions. Several tributaries, such as the White River, Arkansas River, Yazoo River, and Big Black River, contribute to streamflow in this part of the Mississippi River Basin; however, only 75 percent of that streamflow enters the northern Gulf of Mexico through the river's delta (Horowitz, 2010). The remaining streamflow is diverted at the Old River Control Structure downstream from Vicksburg, Mississippi. The diverted flow then merges with the Red River to form the Atchafalaya River about 25 miles upstream from Melville, Louisiana (Meade, 1995; Mossa, 1996). Sites sampled during the 2011 flood in the lower Mississippi-Atchafalaya River Subbasin are shown in figure 5 .

\section{Flood-Control Structures}

Three major flood-control structures are located in the lower Mississippi River Basin: the Birds Point-New Madrid Floodway in Missouri, and the Morganza Floodway and the Bonnet Carré Spillway in Louisiana (fig. 6). The 2011 flood marked the first time in history that the three major flood-control structures of the Mississippi River and Tributaries Project were operated simultaneously (Anderson, 2011; Schneider, 2011). Prior to 2011, the Birds Point-New Madrid Floodway had been operated once during the 1937 flood, the Morganza Floodway had been operated once during the 1973 flood, and the Bonnet Carré Spillway had been operated nine times (Schneider, 2011). Initial preparation of the Birds Point-New Madrid Floodway is required when the stage at Cairo, Illinois (located at the confluence of the upper Mississippi and Ohio Rivers), is approximately 59 feet (U.S. Army Corps of Engineers, 2012a). On May 2, 2011, the Birds Point-New Madrid Floodway was operated, followed by the opening of the Bonnet Carré Spillway on May 9, 2011, to keep streamflow near New Orleans, Louisiana, at approximately 1.25 million cubic feet per second $\left(\mathrm{ft}^{3} / \mathrm{s}\right)$ (Anderson, 2011). Approximately $210 \mathrm{mi}^{2}$ of agricultural lands were inundated by floodwater through the Birds Point-New Madrid Floodway through June 3, 2011 (fig. 6A). All gates on the Bonnet Carré Spillway were closed by June 20, 2011. The Morganza Floodway was opened on May 14, 2011, when streamflow in the Mississippi River reached approximately 1.5 million $\mathrm{ft}^{3} / \mathrm{s}$ (Anderson, 2011), and remained open through July 7, 2011 (fig. 6B).

\section{Methods}

\section{Streamflow Measurement}

The acoustic Doppler current profiler method described by Olson and Norris (2007) was used by the USGS to measure instantaneous streamflow at the sampled stations, where streamflow is the volume of water moving down a stream or river per unit of time, measured in cubic feet per second. At 10 stations (site numbers 2 through 5, 10, 63, 64, and 66 through 68; figs. 4 and 5; table 1), instantaneous streamflow was measured at a separate location from where the waterquality sample was collected. The mean daily streamflow (Q) was calculated and reported by the USGS according to standard procedures (Rantz, 1982). The U.S. Army Corps of Engineers monitored daily streamflow at the Mississippi River at Tarbert Landing, Mississippi (associated with water-quality site number 66; fig. 5; table 1), total outflow at the Old River outflow channel near Knox Landing, Louisiana, and streamflow at the Atchafalaya River at Simmesport, Louisiana (associated with water-quality site number 67; fig. 5; table 1).

\section{Sample Collection, Processing, and Analysis}

Water-quality samples are typically collected 12 to 14 times per year at NASQAN and NAWQA sites. From April to July 2011, the frequency of sample collection was increased at some sites to monitor the effects of the 2011 flood.

Periodic water-quality samples were collected while the Birds Point-New Madrid Floodway was in operation during the flood (fig. 6A). Samples were collected on May 5, 2011, at site numbers 59 and 60 in the floodway and downstream at site numbers 61 and 62 (figs. 5 and $6 A$ ). A sample was also collected at site number 62 on May 18, 2011. Streamflow was measured and sediment samples were collected from the Morganza Floodway at a location different from the 


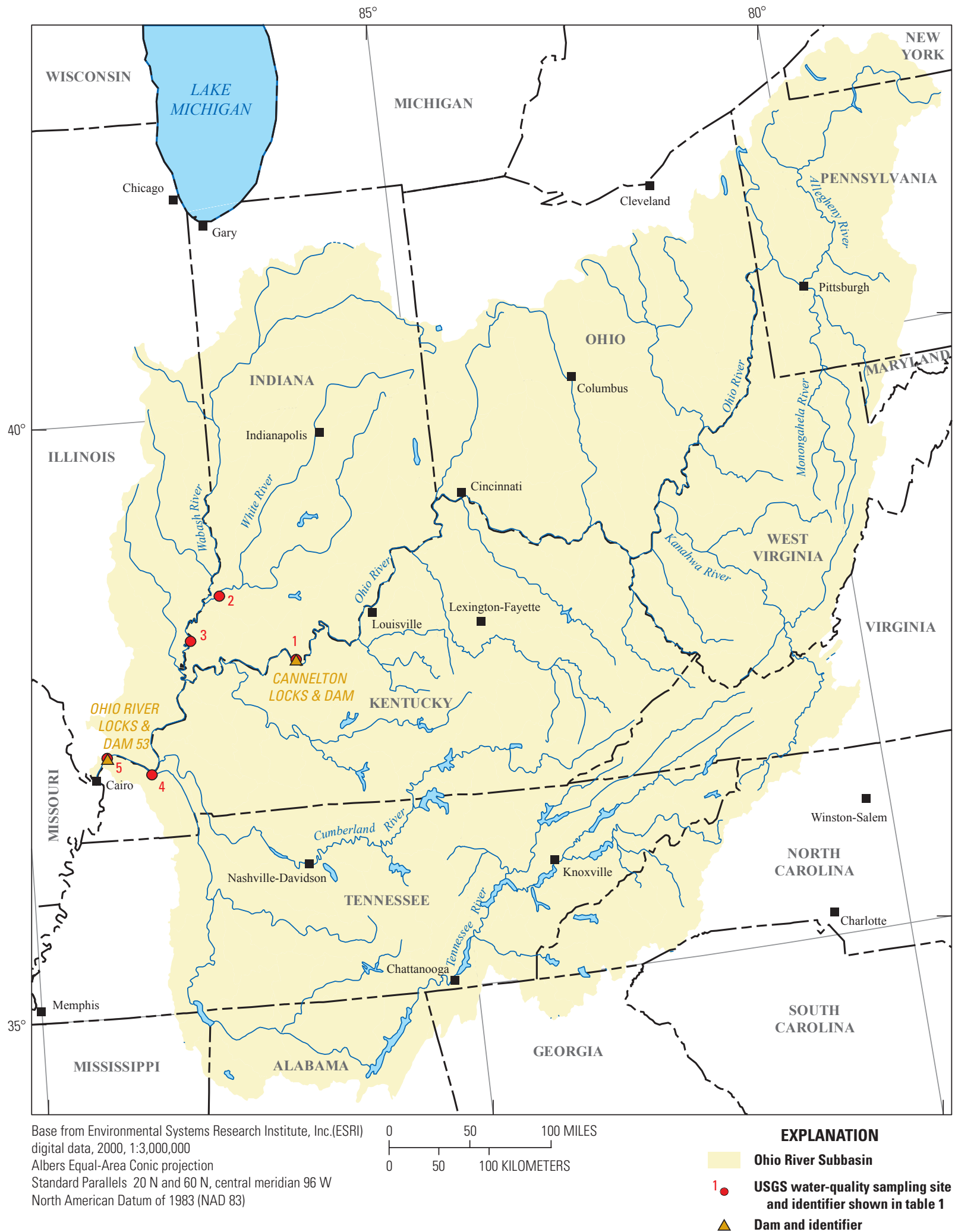

Figure 4. Ohio River Subbasin and sites sampled during the 2011 flood. 


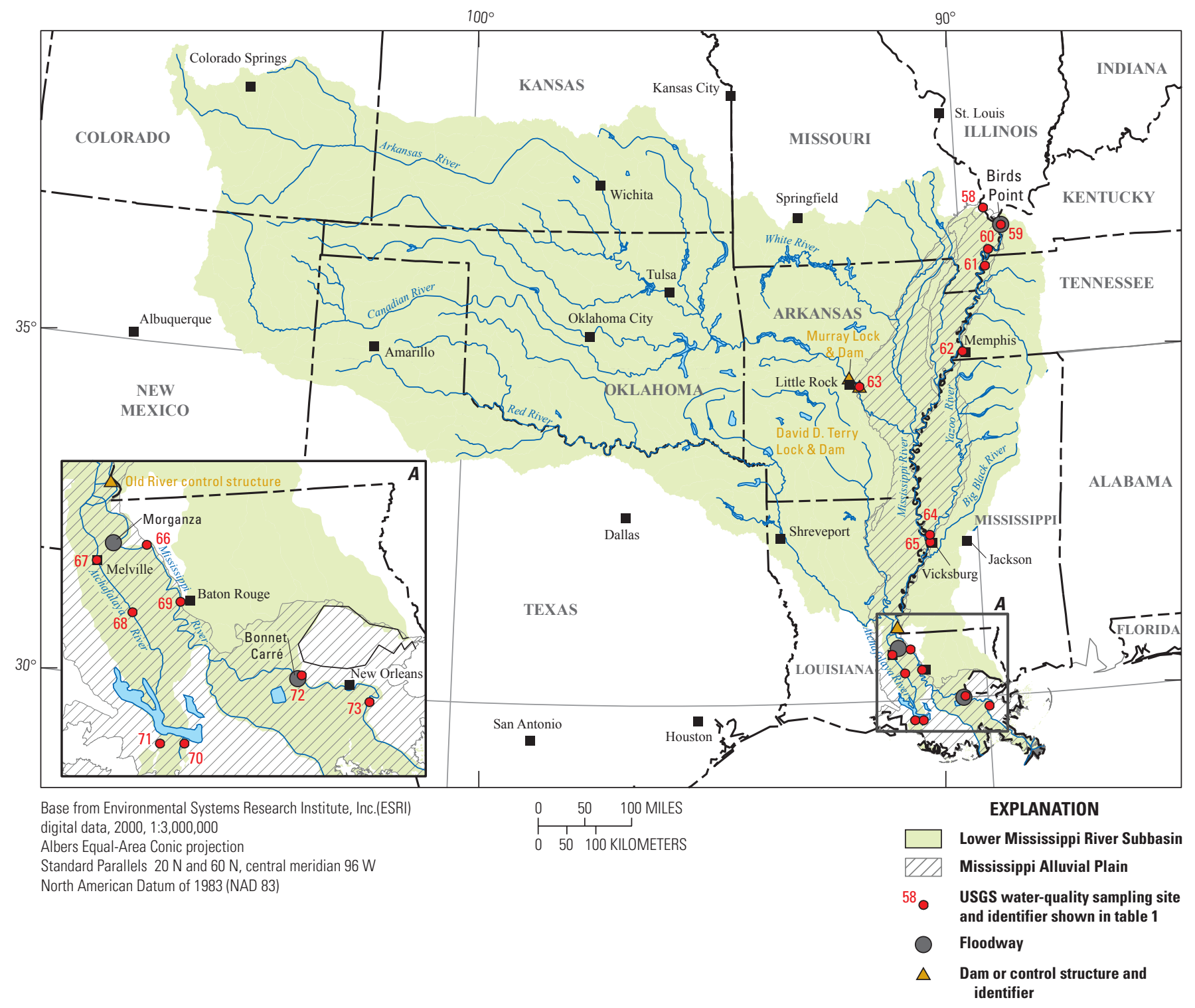

Figure 5. Lower Mississippi-Atchafalaya River Subbasin and sites sampled during the 2011 flood.

water-quality sampling station (site number 68 ; table 1 ). At this separate location, streamflow was measured daily from May 14 through June 27, and sediment samples were collected from May 18 through June 10 (fig. 6B). The Bonnet Carré Spillway was sampled seven times in May and June, and 28 sediment samples were collected at site number 72 during the same time period. Samples for oil and gasoline analysis were collected from the Atchafalaya River at site numbers 70 and 71 (fig. 5; table 1).

Sediment and water-quality samples were collected using isokinetic depth-integrated samplers according to protocols detailed in the USGS National Field Manual for the Collection of Water Quality Data (U.S. Geological Survey, variously dated). The equal-discharge increment sampling method was used to collect a streamflow-weighted sample, representing the entire flow passing through a cross section. The equal-width increment sampling method was used to collect samples at sites 66 through 73 (fig. 5; table 1). Suspended-sediment concentration samples were analyzed at either the USGS sedimentation laboratory in Baton Rouge, Louisiana, or the sedimentation laboratory in Iowa City, Iowa, according to the method described by Guy (1969). Particle-size was analyzed by the USGS sedimentation laboratory in Iowa City, Iowa.

All samples collected for analysis of major ions and nutrients were preserved according to standard USGS protocols and (along with samples analyzed for pesticides) were shipped overnight on ice for analysis at the USGS National Water-Quality Laboratory in Denver, Colorado. Major ions were measured using atomic absorption spectrometry, and nutrient concentrations were quantified using colorimetry (Fishman and Friedman, 1989). Pesticides analyzed at the laboratory were quantified using gas chromatography-mass spectrometry. 

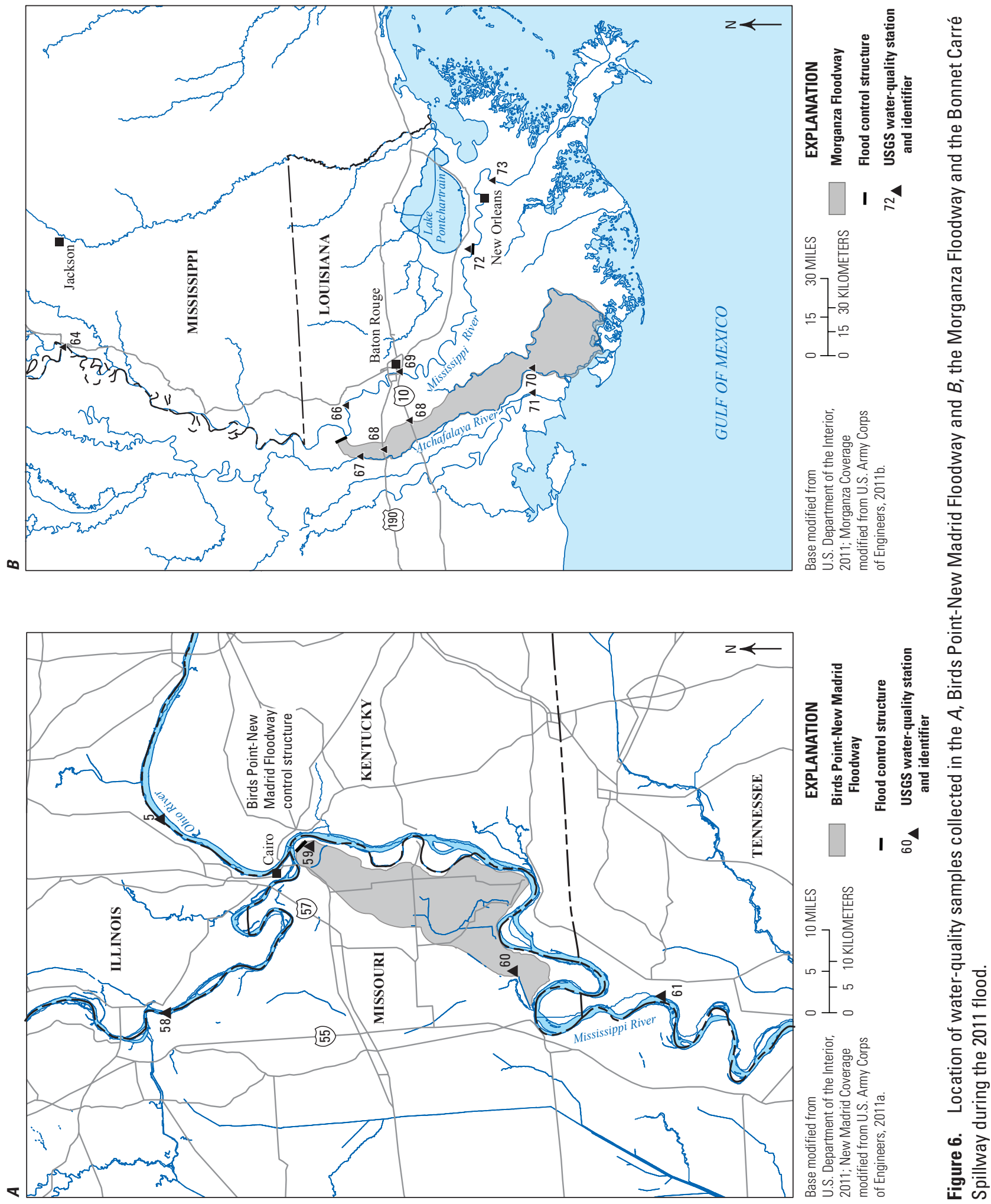
Samples collected for hydrocarbon analysis were chilled to $4^{\circ} \mathrm{C}$ and shipped overnight for analysis at TestAmerica Laboratories, Inc., in Arvada, Colorado. Gasoline-range organics were separated using a purge and trap method and then analyzed using a gas chromatograph with a flame ionization detector (GC-FID), as outlined by the U.S. Environmental Protection Agency (1986). Diesel- range organics were extracted using a separatory funnel liquid-liquid extraction method and analyzed using the GC-FID (U.S. Environmental Protection Agency, 1986). Hexane extractable compounds were separated using solid-phase extraction and analyzed using a gravimetric method (U.S. Environmental Protection Agency, 1999).

\section{Quality-Control Data}

Quality-control data were collected at selected sites from April through July 2011 and included field equipment blanks to measure contamination, replicate samples to estimate variability, and field-spike samples to measure recovery of analytes. Seventeen field equipment blanks were collected at 13 sites within the Mississippi River Basin during the flood period. There were no detections of analyzed pesticides in the field equipment blanks. Data from blanks and spikes are not shown in appendix 1.

Variability in the sample dataset was quantified by collecting 5 to 12 replicates at 10 sites within the Mississippi River Basin during the flood period (appendix 1). The relative percent difference for nutrients ranged from 0.00 to 58 percent, with a median of 3.7 percent. The relative percent difference is computed as

$$
|\mathrm{A}-\mathrm{B}| /[[\mathrm{A}+\mathrm{B}] / 2 \times 100
$$

where A and B represent the environmental sample concentration and the replicate sample concentration, respectively.

Large percent differences generally were observed between pairs when the nutrient of interest was not filtered or was associated with suspended sediment. Variability in the results between the pairs can be introduced during sample collection, as well as during the processing of the samples in the churn splitter (U.S. Geological Survey, variously dated). In one pair of samples for nutrient analysis, a compound was detected in the environmental sample but was not detected in the replicate sample. The relative percent difference for pesticides ranged from 0.00 to 13.3 percent, with a median of 3.02 percent. In one instance, a pesticide was detected in one sample but not the other. The relative percent difference for major ions ranged from 0.0 to 7.8 percent with a median of 1.42 percent. The relative percent difference for total dissolved solids and suspended sediment ranged from 1.8 to 70.3 percent with a median of 5.61 percent.

\section{Water-Quality Data Collected during the 2011 Flood}

Data collected at the 69 water-quality stations and the 3 flood-control structures is summarized in table 1, and the locations of the water-quality stations are shown in figs. 2 through 6 . Results of the water-quality analysis samples are provided in appendixes $1-8$.

\section{Streamflow Characterization}

\section{Comparison of Mean Daily and Instantaneous Streamflow during the 2011 Flood with Historical Streamflow}

Maximum mean daily streamflows measured during the 2011 flood in the upper Mississippi River Subbasin were $228,000 \mathrm{ft}^{3} / \mathrm{s}$ in the Mississippi River at Clinton, Iowa (site number 6); 34,100 $\mathrm{ft}^{3} / \mathrm{s}$ in the Iowa River at Wapello, Iowa (site number 7); 65,500 $\mathrm{ft}^{3} / \mathrm{s}$ in the Des Moines River at Keosaqua, Iowa (site number 8 ); $75,400 \mathrm{ft}^{3} / \mathrm{s}$ in the Illinois River at Valley City, Illinois (site number 9); $361,000 \mathrm{ft}^{3} / \mathrm{s}$ in the Mississippi River at Grafton, Illinois (site number 10); and 853,000 $\mathrm{ft}^{3} / \mathrm{s}$ in the Mississippi River at Thebes, Illinois (site number 58; table 2). Median instantaneous streamflows at site numbers 6,10 , and 58 during the flood period were 2 to 3 times higher than historical median streamflows (fig. 7A). The lowest instantaneous streamflows measured in the upper Mississippi River Subbasin during the 2011 flood were at site numbers 7,8 , and 9; yet, the median instantaneous streamflow at each of these sites during the 2011 flood was still higher than the historical median instantaneous streamflow.

Maximum mean daily streamflows measured during the 2011 flood in the Missouri River Subbasin was $37,000 \mathrm{ft}^{3} / \mathrm{s}$ in the Yellowstone River near Sidney, Montana (site number 15); 46,500 $\mathrm{ft}^{3} / \mathrm{s}$ in the Missouri River at Omaha, Nebraska (site number 20); $15,500 \mathrm{ft}^{3} / \mathrm{s}$ in the Platte River at Louisville, Nebraska (site number 27); $16,300 \mathrm{ft}^{3} / \mathrm{s}$ in the Kansas River at Desoto, Kansas (site number 30); 88,400 $\mathrm{ft}^{3} / \mathrm{s}$ in the Missouri River at Kansas City, Missouri (site number 31); and 274,000 $\mathrm{ft}^{3} / \mathrm{s}$ in the Missouri River at Hermann, Missouri (site number 57; table 2). The median instantaneous streamflow measured at the time of water-quality sampling during the flood period was higher than median instantaneous streamflows measured at times of water-quality sampling historically at site numbers 20, 27, and 57 (fig. $7 B$ ). Median instantaneous streamflow at site numbers 20 and 57 during the flood was about 2.5 times as high as the historical median instantaneous streamflow. 
Table 2. U.S. Geological Survey streamflow station names, station numbers, drainage basin areas, and minimum, maximum, and median streamflow data for April through July 2011 at selected sites in the upper Mississippi River Subbasin, the Missouri River Subbasin, the Ohio River Subbasin, and the lower Mississippi-Atchafalaya River Subbasin.

[The complete list of water-quality stations are shown in table 1 and site locations are shown in figures 2-6. USGS, U.S. Geological Survey; $\mathrm{ft}^{3} / \mathrm{s}$, cubic foot per second; $\mathrm{mi}^{2}$, square mile; --, data not available]

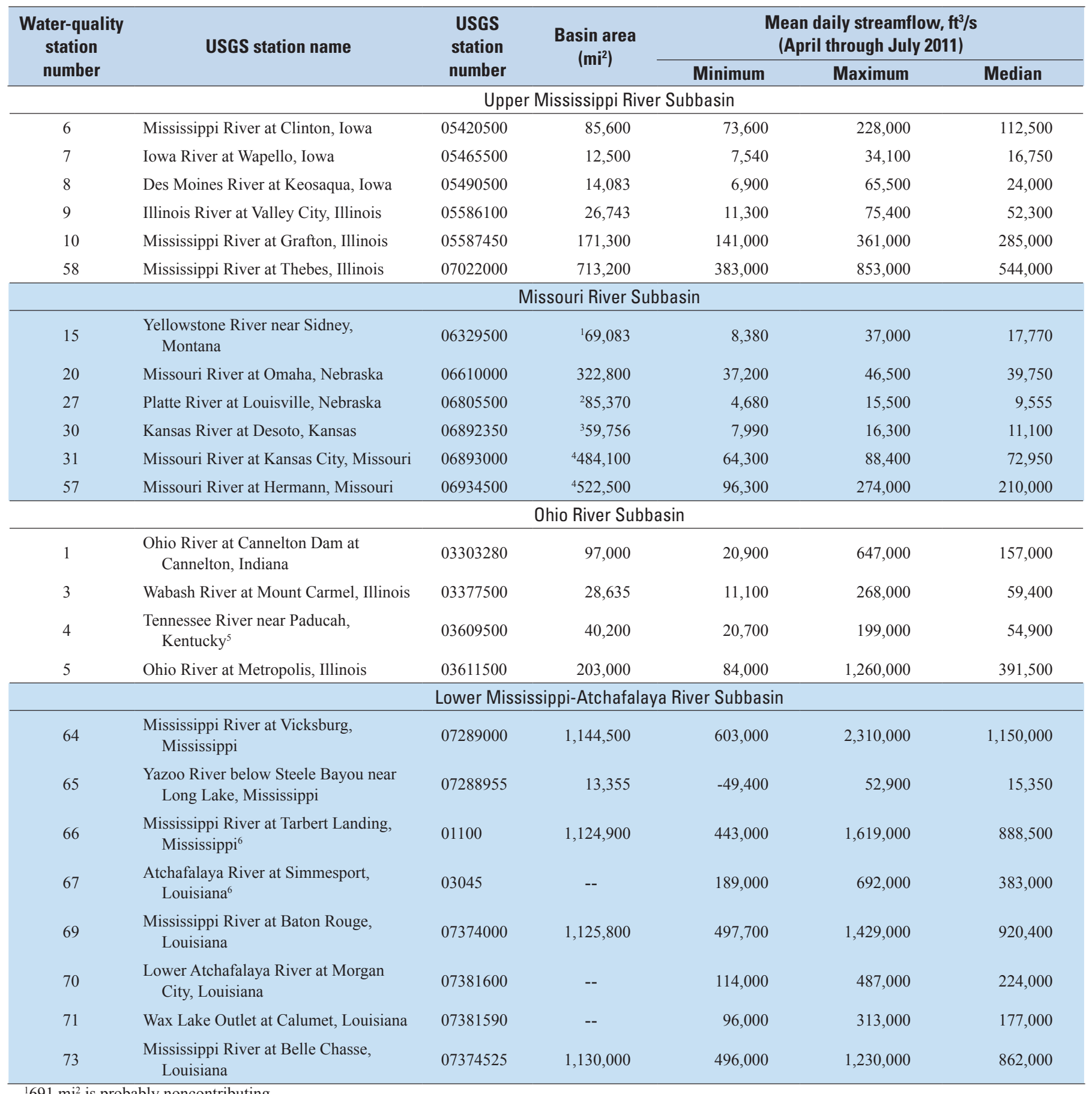

${ }^{1} 691 \mathrm{mi}^{2}$ is probably noncontributing.

${ }^{2} 14,370 \mathrm{mi}^{2}$ is probably noncontributing.

${ }^{3} \mathrm{~A}$ large area is noncontributing.

${ }^{4}$ The 3,959 $\mathrm{mi}^{2}$ in the Great Divide Basin are not included.

${ }^{5}$ Streamflow data collected by the Tennessee Valley Authority.

${ }^{6}$ Streamflow data collected by the U.S. Army Corps of Engineers. 

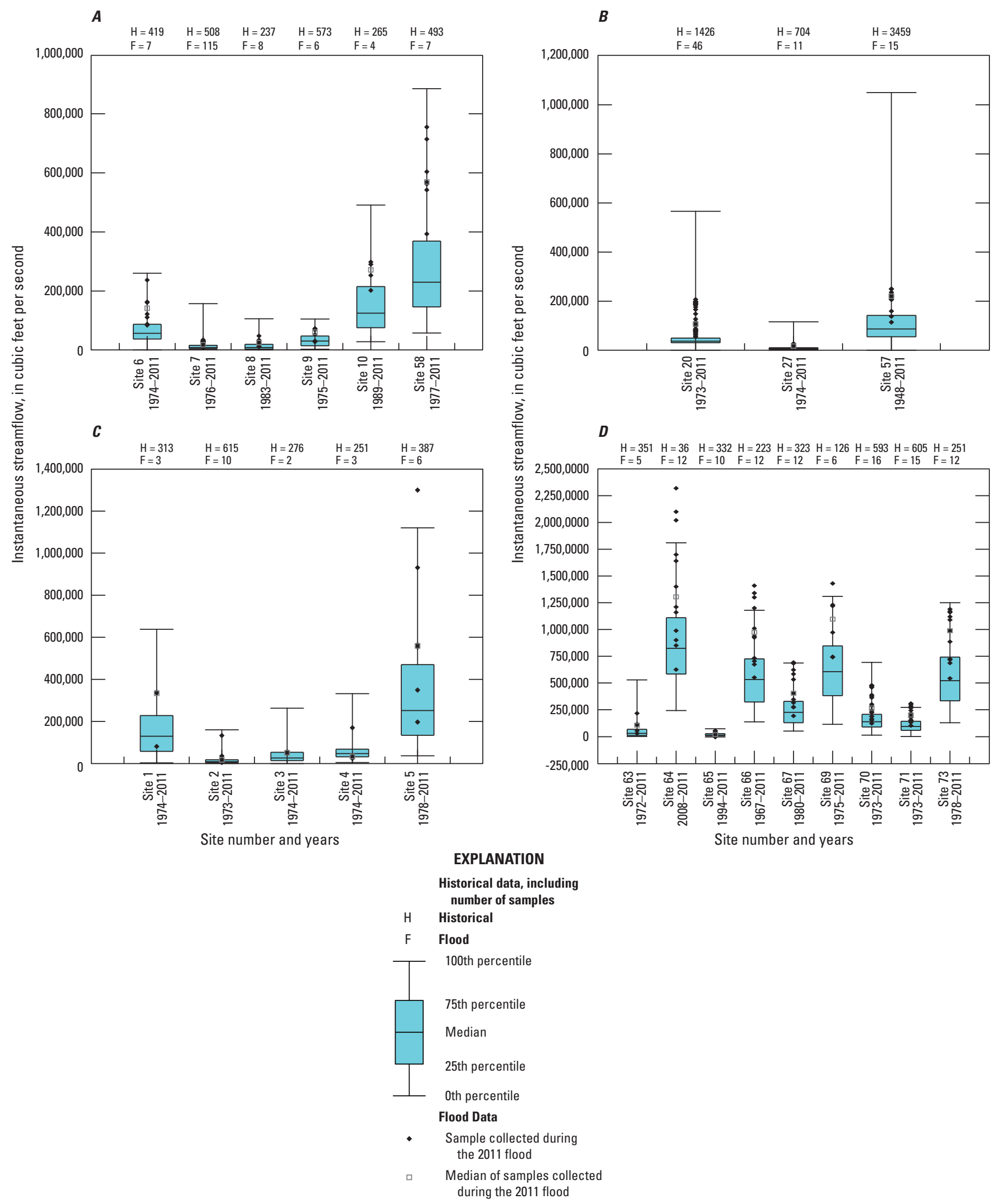

Figure 7. Box plots comparing historical instantaneous streamflow with instantaneous streamflow measured during the 2011 flood at selected sites in $A$, the upper Mississippi River Subbasin, $B$, the Missouri River Subbasin, $C$, the Ohio River Subbasin, and $D$, the lower Mississippi-Atchafalaya River Subbasin. [Hist., historical; Fld., flood]. The date ranges shown indicate the period of record for instantaneous streamflow data. 
Maximum mean daily streamflows measured during the 2011 flood in the Ohio River Subbasin were $647,000 \mathrm{ft}^{3} / \mathrm{s}$ in the Ohio River at Cannelton Dam (site number 1); 268,000 $\mathrm{ft}^{3} / \mathrm{s}$ in the Wabash River (site number 3); 199,000 $\mathrm{ft}^{3} / \mathrm{s}$ in the Tennessee River (site number 4); and 1.26 million $\mathrm{ft}^{3} / \mathrm{s}$ in the Ohio River at Metropolis (site number 5; table 2). In general, instantaneous streamflows measured at the time of waterquality sampling during the flood were within the range of instantaneous streamflows measured historically at site numbers 1 to 5 located within the subbasin (fig. 7C). Median instantaneous streamflows during the flood period were higher than historical observations at site numbers 1,3 , and 5 . At site number 5, the median instantaneous streamflow during the flood period was more than twice the historical median streamflow, and the highest instantaneous streamflow measured at this site for the period of record $\left(1.3\right.$ million $\left.\mathrm{ft}^{3} / \mathrm{s}\right)$ occurred during the 2011 flood. Instantaneous median streamflow at site number 2 during the flood was approximately the same as the historical median; whereas at site number 4, the median instantaneous streamflow during the flood was lower than the historical median. The lower streamflow at site number 4 was most likely a consequence of upstream dams being used in the basin to dampen the effects of floodwaters that would have increased streamflow and stage at Cairo, Illinois (Camillo, 2012), the city located at the confluence of the upper Mississippi and Ohio Rivers.

Maximum mean daily streamflows measured during the 2011 flood in the lower Mississippi-Atchafalaya River Subbasin were 2,310,000 $\mathrm{ft}^{3} / \mathrm{s}$ for the Mississippi River at Vicksburg, Mississippi (site number 64); 1,619,000 $\mathrm{ft}^{3} / \mathrm{s}$ for the Mississippi River at Tarbert Landing, Mississippi (site number 66); 1,429,000 $\mathrm{ft}^{3} / \mathrm{s}$ for the Mississippi River at Baton Rouge, Louisiana (site number 69 ); 1,230,000 $\mathrm{ft}^{3} / \mathrm{s}$ for the Mississippi River at Belle Chasse, Louisiana (site number 73); $692,000 \mathrm{ft}^{3} / \mathrm{s}$ for the Atchafalaya River at Simmesport, Louisiana (site number 67); 313,000 $\mathrm{ft}^{3} / \mathrm{s}$ at Wax Lake Outlet at Calumet, Louisiana (site number 71); and 487,000 $\mathrm{ft}^{3} / \mathrm{s}$ for the Lower Atchafalaya River at Morgan City, Louisiana (site number 70; table 2). Median instantaneous streamflow during the flood period was higher than the historical median at all stations in the lower Mississippi-Atchafalaya River Subbasin except for streamflow at site number 65 (fig. 7D). This site was in backwater during the month of May 2011, which resulted in negative flow during that period. During the flood period, median instantaneous streamflows at site numbers 64, 69, and 73 on the main stem of the lower Mississippi River were approximately two times higher than the historical medians. Median instantaneous streamflows in the Atchafalaya River Basin at site numbers 67, 70, and 71 were about two times higher during the flood compared to historical observations. In the Arkansas River (site number 63), the median instantaneous streamflows were almost 4 times higher than the historical median values. Water-quality samples obtained during the flood period corresponded to well-aboveaverage streamflow at the majority of the stations throughout the Mississippi River Basin.

\section{Flood Period Hydrographs}

\section{Upper Mississippi River Subbasin}

Increases in streamflow in the Upper Mississippi River Subbasin were influenced by record rainfall and snowmelt (Vining and others, 2013). The upper and lower portions of the subbasin experienced flow increases at differing times because of the timing of snowmelt and rainfall, which resulted in a bimodal hydrograph at site numbers 10,57 , and 58 in the lowermost subbasin (fig. 8). In March 2011, the early flooding in Minnesota (upper Mississippi River Subbasin) was caused by rapid snowmelt and spring rains (Vining and others, 2013). This was followed by above-average precipitation over the entire subbasin from May through July (Vining and others, 2013). In the Missouri River Subbasin, melting of record snowpack in May combined with rainfall throughout the subbasin from May through July resulted in exceptionally large streamflow (Vining and others, 2013). Maximum streamflow in the Mississippi River at Clinton, Iowa $\left(228,000 \mathrm{ft}^{3} / \mathrm{s}\right.$; site number 6$)$, occurred on April 21, 2011, and then declined throughout the remainder of the flood period. In contrast, streamflow in the Iowa River at Wapello, Iowa (site number 7), reached a maximum on June 16, 2011. The profiles of the hydrographs for site numbers 10,57 , and 58 are similar, indicating flood peaks both in the spring and mid-summer. In this case, the spring peak was caused by rainfall, with relatively minor contribution from Minnesota snowmelt, and the mid-summer peak was caused by relatively equal contributions of snowmelt and rainfall. A streamflow maximum of $274,000 \mathrm{ft}^{3} / \mathrm{s}$ occurred at site number 57 on May 28, 2011, with a secondary peak of $261,000 \mathrm{ft}^{3} / \mathrm{s}$ occurring on July 2 . Two streamflow peaks, both measuring $361,000 \mathrm{ft}^{3} / \mathrm{s}$, occurred at site number 10 on April 30, 2011, and June 19, 2011. A streamflow peak of $853,000 \mathrm{ft}^{3} / \mathrm{s}$ occurred at site number 58 on May 2, 2011, with a secondary peak of $621,000 \mathrm{ft}^{3} / \mathrm{s}$ occurring on July 5.

\section{Missouri River Subbasin}

Exceptional snowpack in the upper part of the Missouri River Subbasin, along with heavy rainfall throughout most of the area from May through July 2011 resulted in the release of record amounts of water from 5 of the 6 major dams along the Missouri River in the month of May, and record monthly releases from all 6 dams in June and July 2011 to prevent overflow and possible failure (U.S. Army Corps of Engineers, 2012b). The U.S. Army Corps of Engineers attempted to regulate the release of water over approximately 850 miles of the river from the Garrison Dam in North Dakota to the confluence with the Mississippi River at St. Louis, Missouri. The shape of the hydrograph for the Yellowstone River near Sidney, Montana (site number 15), one of the major river basins draining into the upper Missouri River, shows a substantial peak in late May 2011, caused by record rainfall in the upper part of the Missouri Subbasin (fig. 9) (Vining 


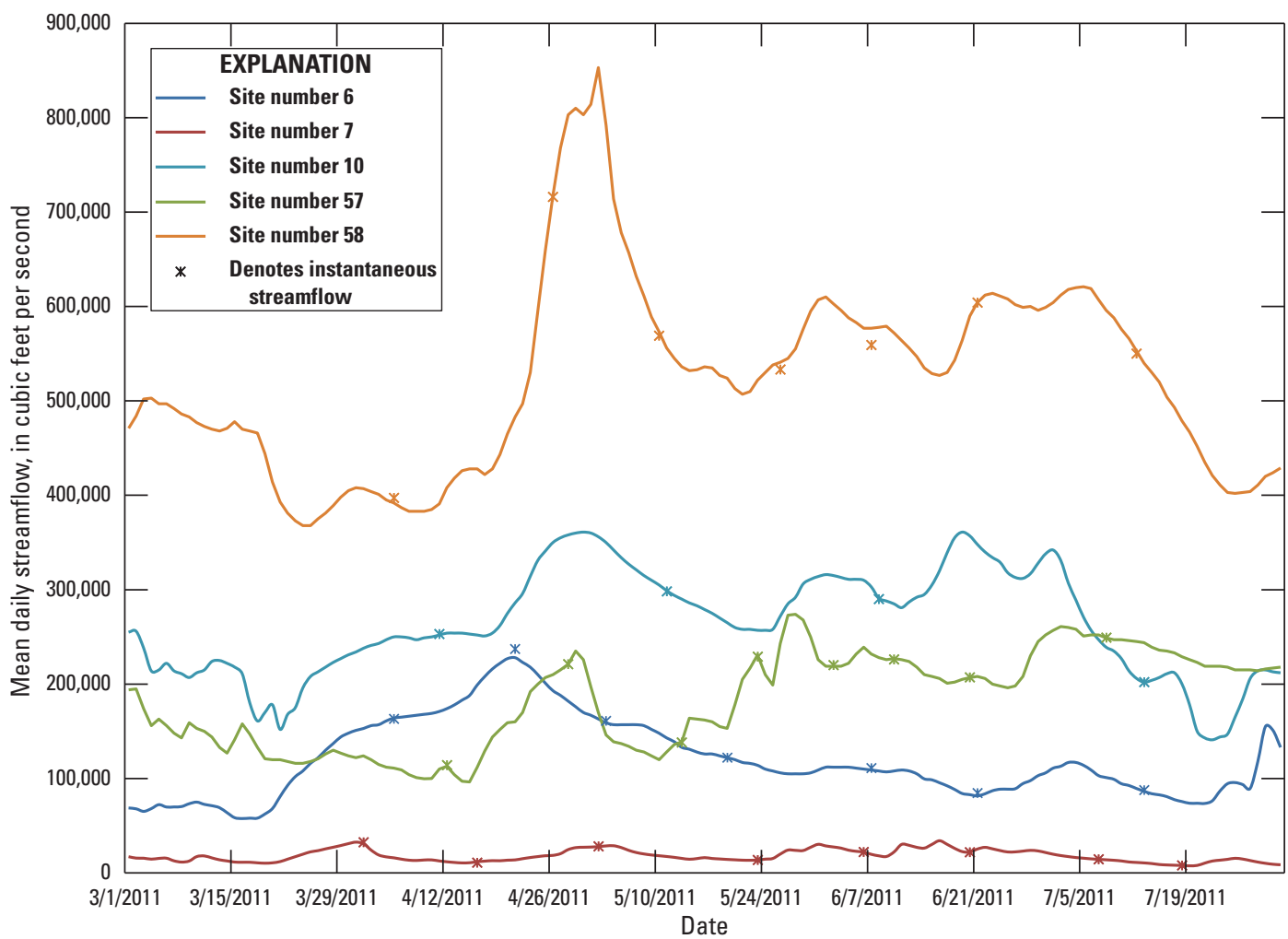

Figure 8. Mean daily streamflow in the upper Mississippi River Subbasin from March through July 2011 and the instantaneous streamflow at the time of water-quality data collection.

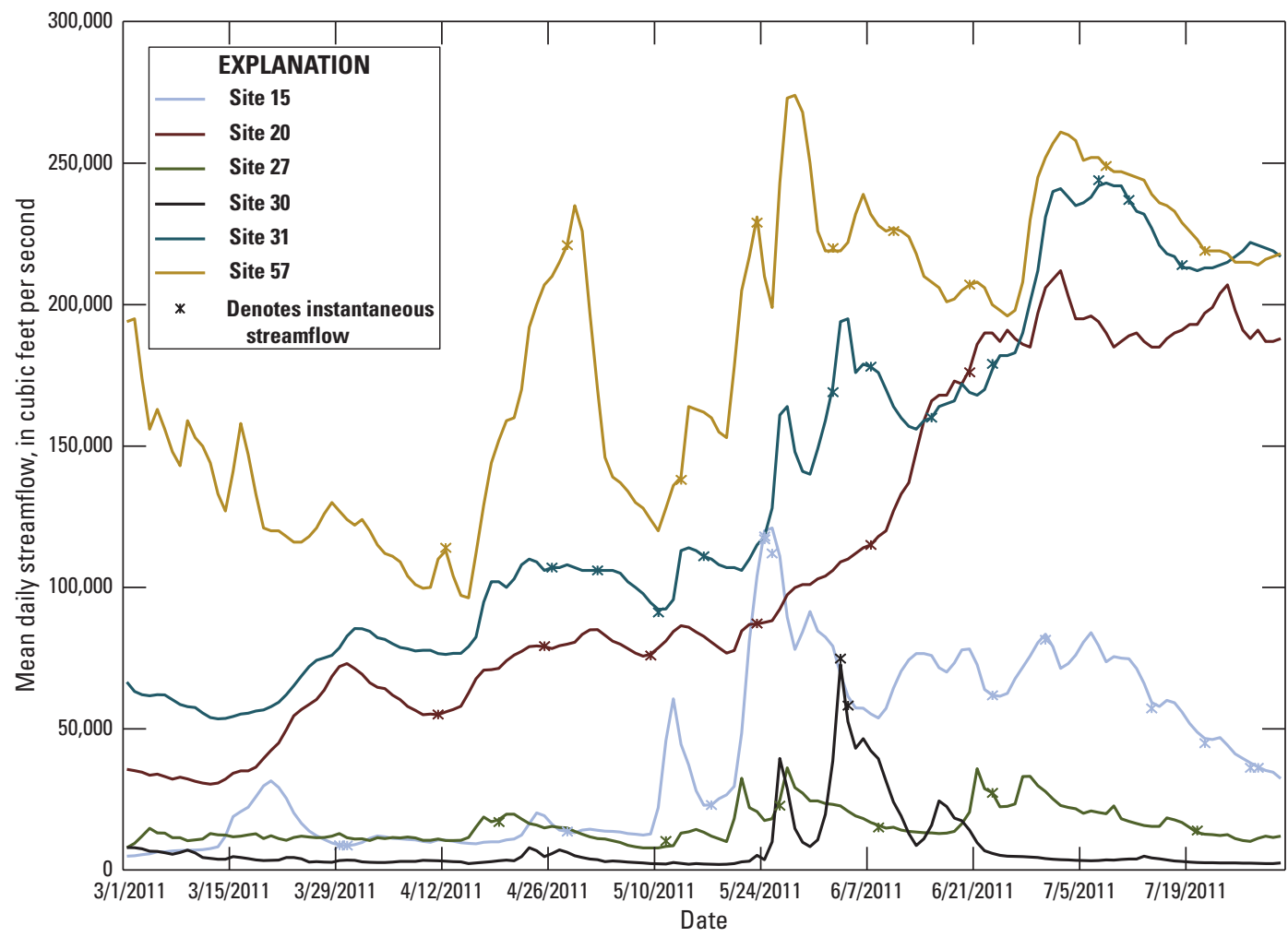

Figure 9. Mean daily streamflow in the Missouri River Subbasin from March through July 2011 and the instantaneous streamflow at the time of water-quality data collection. 
and others, 2013). Increasing flows and (or) peaks also begin around the same time period for the following gaging stations: Missouri River at Omaha, Nebraska (site number 20); Missouri River at Kansas City, Kansas (site number 31); and Missouri River at Hermann, Missouri (site number 57). Streamflows remained high at these three sites from June through July 2011 as the U.S. Army Corps of Engineers began releasing water from the six major dams along the upper Missouri River. Of the three sites just mentioned, however, only site number 20 had a record crest (the second highest ever recorded at that site), which was recorded on July 2, 2011, measured 36.29 feet, and had an associated discharge of $212,000 \mathrm{ft}^{3} / \mathrm{s}$.

\section{Ohio River Subbasin}

Streamflow in the Ohio River Subbasin began to increase in March because of precipitation in the subbasin (fig. 10). Further rainfall throughout April increased streamflow in the Ohio River at Metropolis, Illinois (site number 5), to over 1.2 million $\mathrm{ft}^{3} / \mathrm{s}$ during the first week of May; site number 5 is the last upstream streamflow monitoring in the Ohio River Subbasin before the confluence of the upper Mississippi and Ohio Rivers. The profiles of the hydrographs at Cannelton Dam (site number 1) and Metropolis (site number 5) were similar; however, peak streamflow occurred a week earlier at site number 1 than at site number 5 . The increases and decreases in streamflow at the Tennessee River near Paducah, Kentucky (site number 4) were dependent upon the release of water from dams within the Cumberland River Basin, which is upstream of the Tennessee River. As river stage at Cairo, Illinois, began to increase, additional water was impounded by the dams to try to prevent the stage from exceeding a maximum of 61 feet (Camillo, 2012). Around April 28, 2011, flow from the dams was reduced, and the hydrograph for site number 4 shows this sharp decline in streamflow (fig. 10). As storage capacity in the dams decreased, the water was slowly released to maintain storage; however, by May 1, 2011, water was being released from the dams at a rate 2.5 times greater than that of the previous day (Camillo, 2012). On May 2, 2012, the Birds Point-New Madrid Floodway was activated, which allowed for the release of the remaining impounded water from the dams. Streamflow at site number 4 increased steadily thereafter until reaching a peak of about 184,000 ft³ $/ \mathrm{s}$ on May 4, 2011.

Streamflow contributed by record rainfall in the Ohio River Subbasin was the primary contributor to flow in the lower Mississippi-Atchafalaya River Subbasin during the months of March, April, and May (fig. 11). Melting of record snowpack during late May in the Missouri River Subbasin and above normal precipitation from May through July in the upper Mississippi River Basin contributed to the majority of streamflow in the lower Mississippi-Atchafalaya River

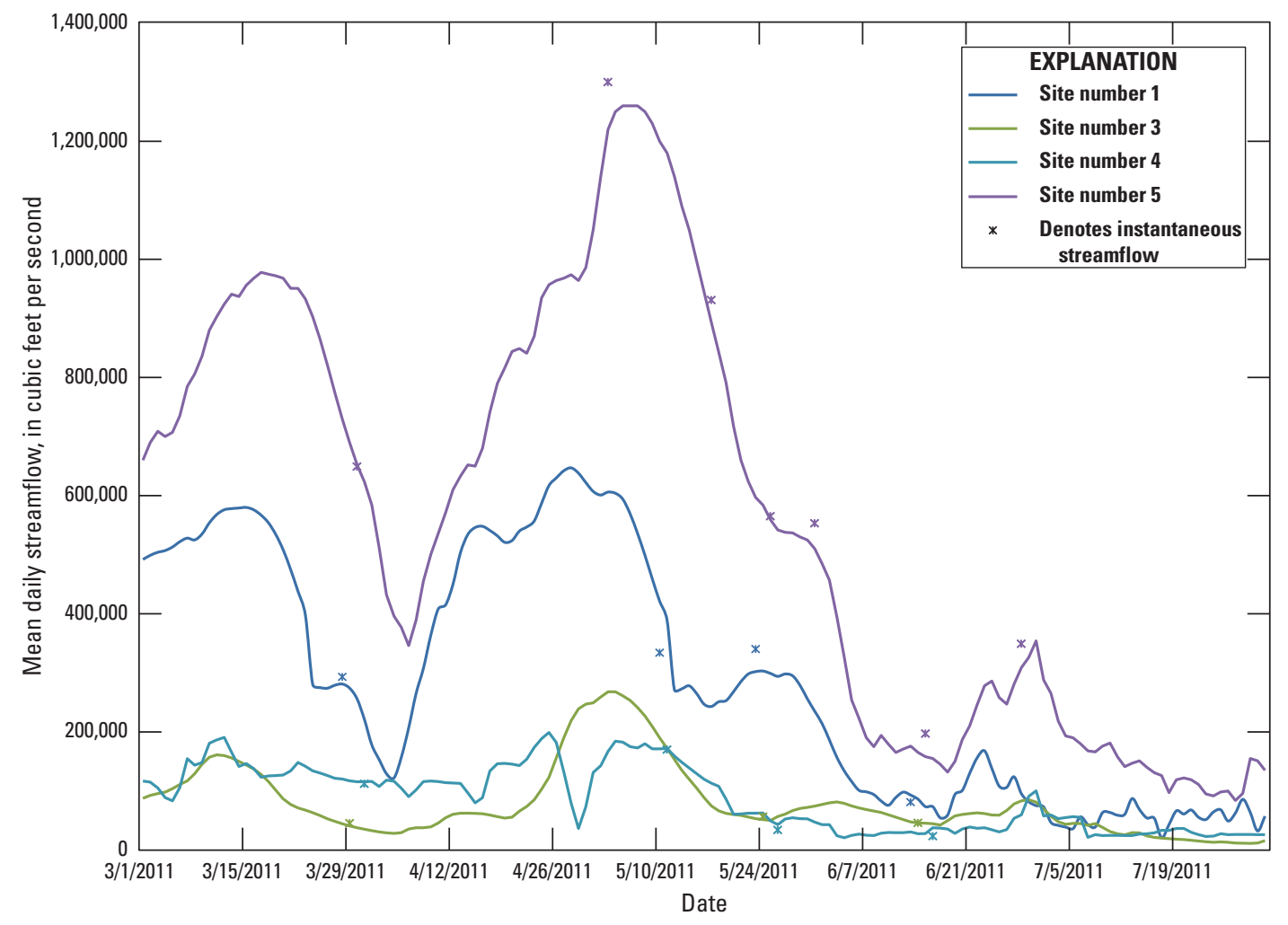

Figure 10. Mean daily streamflow in the Ohio River Subbasin from March through July 2011 and the instantaneous streamflow at the time of water-quality data collection. 


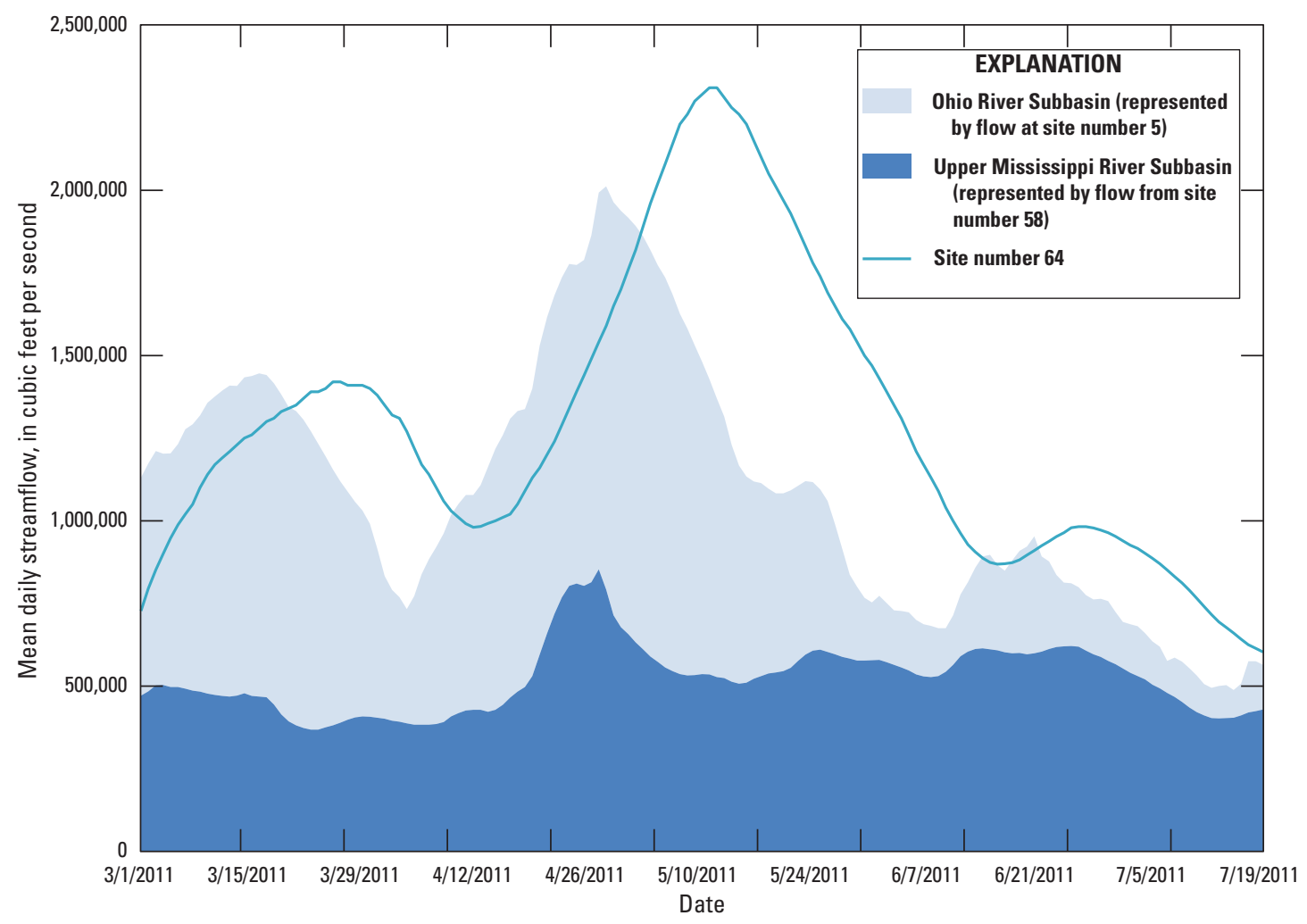

Figure 11 Contribution of streamflow to the lower Mississippi-Atchafalaya River Subbasin from the upper Mississippi River and Ohio River Subbasins. The upper Mississippi River Subbasin flow contribution includes flow from the Missouri River Subbasin. Cumulative streamflow, represented by the two shaded areas, is the combined streamflow from the upper Mississippi and Ohio Rivers.

Subbasin during June and July. Average streamflow leaving the Ohio River Subbasin in April and May was 694,100 and $902,000 \mathrm{ft}^{3} / \mathrm{s}$, respectively, equaling 58 percent of the total streamflow entering the lower Mississippi-Atchafalaya River Subbasin during those months. The average streamflow contributed to the lower Mississippi-Atchafalaya River Subbasin from the upper Mississippi River Basin during June and July was 580,000 and 507,000 $\mathrm{ft}^{3} / \mathrm{s}$, respectively. These contributions were about 71 percent of the total streamflow in June and 78 percent of the total streamflow in July. Land use in the Ohio River Subbasin is primarily urban and forested land, whereas the Missouri River and upper Mississippi River Basin are primarily agricultural land with some rangeland. The timing and contribution of the streamflow from the two different source areas are important in determining which chemicals and other potential contaminants enter the lower Mississippi-Atchafalaya River Subbasin through overland runoff or receding water from inundated lands.

Between the confluence of the upper Mississippi and Ohio Rivers and the streamgaging station at the Mississippi River at Vicksburg, Mississippi (site number 64), flow was diverted through the Birds Point-New Madrid Floodway from May 2 through June 3, 2011 (fig. 6A). The average streamflow during the period that the floodway was open was approximately $170,000 \mathrm{ft}^{3} / \mathrm{s}$. The highest streamflow measured during the flood period in the lower Mississippi-Atchafalaya River Subbasin was at site number 64, where 2.31 million $\mathrm{ft}^{3} / \mathrm{s}$ was measured on May 18, 2011 (fig. 12). Between Vicksburg and Tarbert Landing, Mississippi, the Mississippi River bifurcates, and approximately 27 percent of the streamflow measured during the flood period was diverted into the Atchafalaya River Basin through the Old River Control Structure (Welch and others, 2012). The streamflow diverted through the structure from April through July 2011 averaged about $370,000 \mathrm{ft}^{3} / \mathrm{s}$. The maximum streamflow during the flood period measured at Tarbert Landing (site number 66) was 1,619,000 ft $3 / \mathrm{s}$ on May 21, 2011 (fig. 12). Maximum streamflow at Baton Rouge (site number 69) was 1,429,000 ft $3 / \mathrm{s}$, measured on May 18, 2011. Between site numbers 66 and 69 , an average of $66,450 \mathrm{ft}^{3} / \mathrm{s}$ flowed through the Morganza Floodway from May 14 to July 7, 2011. Downstream of Baton Rouge, the Bonnet Carré Spillway was activated on May 9, 2011. This flood-control structure diverted an average of $208,000 \mathrm{ft}^{3} / \mathrm{s}$ of streamflow into Lake Ponchartrain above New Orleans, Louisiana, from May 9 through June 20, 2011. Streamflow at Belle Chasse (site number 73), Louisiana, the lowermost streamgage on the main stem of the Mississippi River, is tidally influenced, which is evident in the daily fluctuation of streamflow shown in fig. 12. Maximum streamflow measured during the flood period at site number 73 was 1.23 million $\mathrm{ft}^{3} / \mathrm{s}$ on May 14 and 15, 2011. 


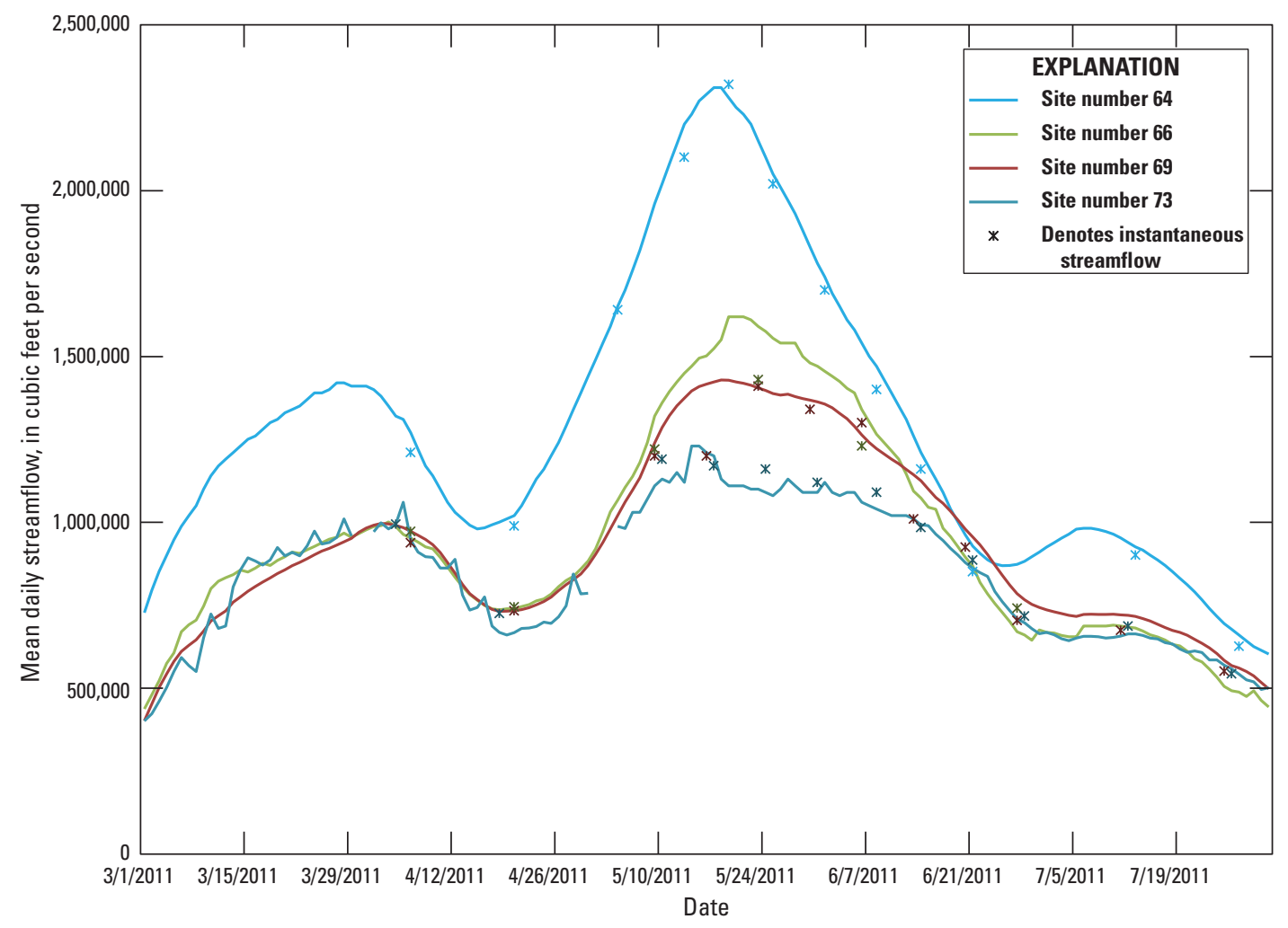

Figure 12. Mean daily streamflow at sites on the main stem in the lower MississippiAtchafalaya River Subbasin from March through July 2011 and the instantaneous streamflow at the time of water-quality data collection.

The diverted flow through the Old River Control Structure drains into the Atchafalaya River Basin. The maximum streamflow measured during the flood period at the Old River outflow near Knox Landing, Louisiana, was $671,000 \mathrm{ft}^{3} / \mathrm{s}$ on May 14, 2011. Downstream from the Old River Control Structure, the Red River merges with the Atchafalaya River above the gage at Simmesport, Louisiana (site number 67). The maximum streamflow measured along the Red River at Alexandria, Louisiana, was $65,000 \mathrm{ft}^{3} / \mathrm{s}$ on May 11, 2011. The highest streamflow measured at any site in the Atchafalaya River Basin was $692,000 \mathrm{ft}^{3} / \mathrm{s}$ at site number 67 on May 24, 2011 (fig. 13). Below site number 67, outflow from the Morganza Floodway entered the Atchafalaya River at an average rate of about $66,450 \mathrm{ft}^{3} / \mathrm{s}$ for the period that the floodway was in operation, as previously stated. The Atchafalaya River bifurcates below the outlet of the Morganza Floodway, and water enters the Gulf of Mexico downstream of Morgan City (site number 70) and through the Wax Lake Outlet (site number 71). The maximum streamflows at these two sites, respectively, were $487,000 \mathrm{ft}^{3} / \mathrm{s}$ on May 30, 2011 and 313,000 ft $3 / \mathrm{s}$ on May 28, 2011 (fig. 13). Approximately 55 million $\mathrm{ft}^{3}$ of water entered the Gulf of Mexico through the Atchafalaya River Basin, which is almost half the volume of water that entered the Gulf of Mexico through the main stem past the Bird's Foot Delta (102 million $\left.\mathrm{ft}^{3}\right)$.

\section{Comparison of Peak Stage and Streamflow of the 2011 Flood to Those of Historic Floods}

\section{Missouri River Subbasin}

There have been numerous historical floods in the Missouri River Subbasin, with the first detailed account of flooding in 1881. A spring flood caused by rapid snowmelt in April 1943 initiated the Flood Control Act of 1944, also known as the Pick-Sloan Missouri Basin Program. This plan included the construction of numerous dams and reservoirs to provide flow regulation for flood control and navigation. Heavy snowfall in Montana, North Dakota, and South Dakota in the winter of 1951 followed by unseasonably warm weather the following spring led to the flood-ofrecord at site numbers 17 and 20 in April 1952, with record crests of 44.28 and 40.20 feet, respectively (table 3; U.S. Geological Survey, 2012a). In 1993, record amounts of rain throughout the basin resulted in major flooding from April through October. Record crests were recorded at site number 29 (32.07 feet), site number 31 (48.87 feet), and site number 57 (36.97 feet) (table 3). As previously 


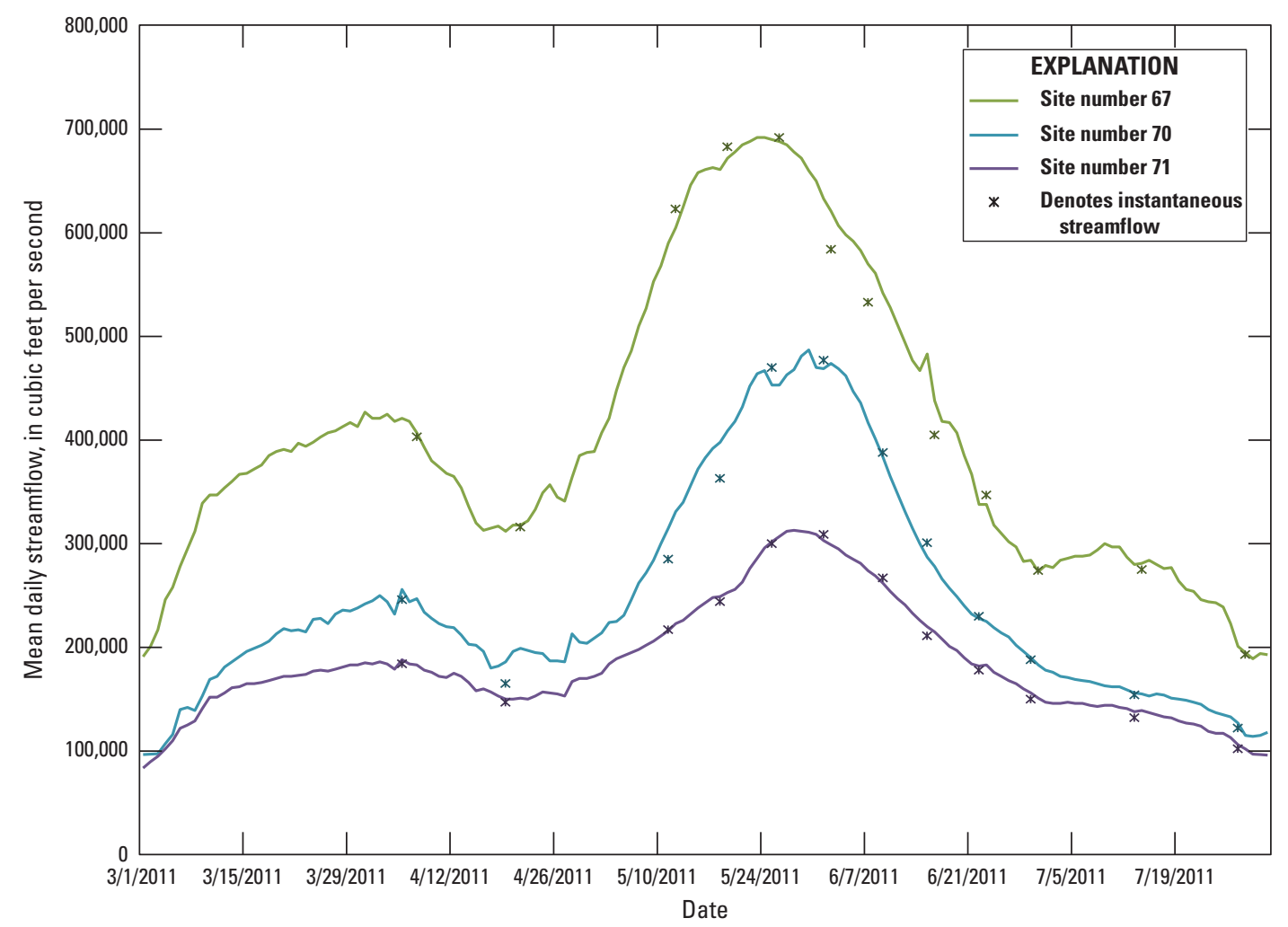

Figure 13. Mean daily streamflow at sites on the Atchafalaya River in the lower MississippiAtchafalaya River Subbasin from March through July 2011 and the instantaneous streamflow at the time of water-quality data collection.

described, flooding occurred in the summer of 2011 as the result of several factors: heavy snow pack, excessive rainfall in May, and record water releases from reservoirs in the upper Missouri River Subbasin. During June and July 2011, the Missouri River was above flood stage at some point in time within every state it crosses (U.S. Geological Survey, 2011); however, the volume of water in the river was less than that during the 1952 flood. During the 1952 flood, maximum discharge at site number 20 occurred on April 18, and was $396,000 \mathrm{ft}^{3} / \mathrm{s}$, compared to $217,000 \mathrm{ft}^{3} / \mathrm{s}$ on July 2, 2011 (fig. 7B) (U.S. Geological Survey, 2012a). On April 22, 1952, streamflow at site number 29 was $397,000 \mathrm{ft}^{3} / \mathrm{s}$, compared to $230,000 \mathrm{ft}^{3} / \mathrm{s}$ on July 28,2011 (table 3; U.S. Geological Survey, 2012b).

\section{Ohio River Subbasin and the Lower Mississippi- Atchafalaya River Subbasin}

The Great Flood of 1927 was the most devastating flood in U.S. history and resulted in the Mississippi River and Tributaries Project, which was authorized by the Flood Control Act of 1928. The project called for the creation of a levee system to prevent overflow on developed alluvial lands, floodways to divert excess streamflow past critical reaches, channel improvements and stabilization, and tributary basin improvement (Mississippi River Commission, 2008). The system was tested 84 years later during the 2011 flood, when the stage at Vicksburg (site number 64) reached a height exceeded only by what the stage would have been in 1927 if the levees had held (fig. 14).

Because of its size, flooding in parts of the lower Mississippi-Atchafalaya River Subbasin may result in little or no change in streamflow conditions in downstream reaches of the river. To put the 2011 flood in perspective, peak streamflow at selected sites (site number 5, 7, 58, 64, and 66) in the upper Mississippi River Subbasin, the Ohio River Subbasin, and the lower Mississippi-Atchafalaya River Subbasin (figs. 2, 4, and 5) were compared to peak streamflow at those same stations during the floods of 1973, 1993, and 2008 (table 3). The effects of the 1993 and 2008 floods were largely realized in the upper Mississippi River Subbasin, whereas the 1973 flood had a basin-wide influence. All seemed to result from wet antecedent conditions during the months prior to peak streamflow, which left the ground saturated and resulted in large runoff events (Chin and others, 1975; Parrett and others, 1993; National Climate Data Center, 2008).

Prior to 2011, peak streamflow at site number 5 was 989,000 ft 3 /s, during the 1973 flood on March 26, 1973 (table 3). On May 6, 2011, peak streamflow at the site was 1.28 million $\mathrm{ft}^{3} / \mathrm{s}$, a 29 -percent increase over the peak streamflow measured during the 1973 flood. In contrast, peak streamflow at site numbers 7 and 58 occurred prior to 
Table 3. Maximum stages and streamflows for 2011 and selected largest-flood years at select U.S. Geological Survey streamflow stations in the Mississippi River Basin.

[The complete list of water-quality station numbers are shown in table 1 and site locations are shown in figures 2-6. USGS, U.S. Geological Survey; mi², square mile; $\mathrm{ft}$, foot; $\mathrm{ft}^{3} / \mathrm{s}$, cubic foot per second; -, data not available]

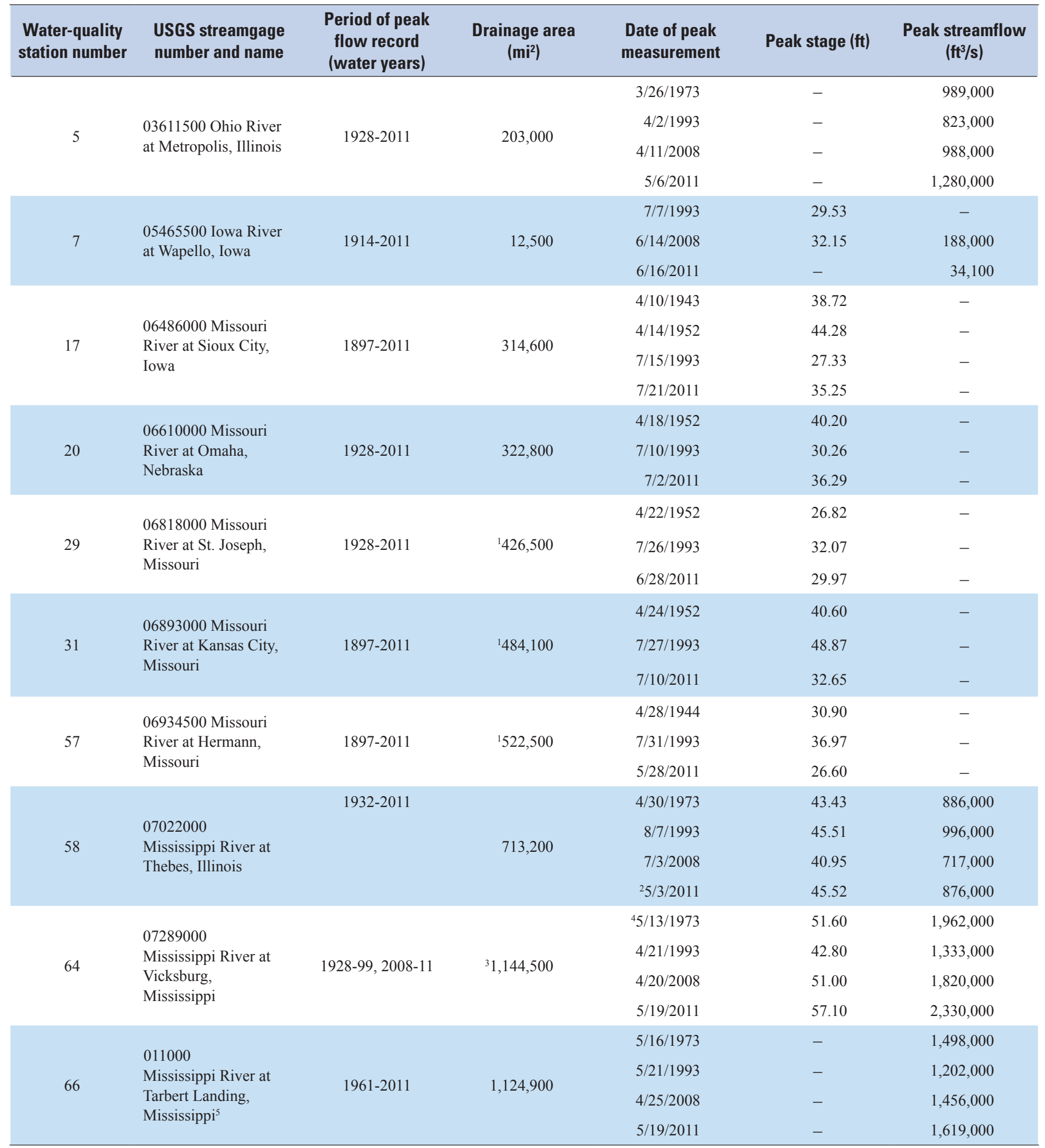

${ }^{1}$ Drainage area does not include the 3,959 $\mathrm{mi}^{2}$ in the Great Divide basin.

${ }^{2}$ Peak streamflow was measured on May 2, 2011.

${ }^{3} 4,000 \mathrm{mi}^{2}$ is probably noncontributing (is from the Great Divide basin in Southern Wyoming).

${ }^{4}$ Peak streamflow was measured on May 12, 1973.

${ }^{5}$ Streamflow data collected by the U.S. Army Corps of Engineers. 
the 2011 flood. Peak streamflow at site number 7 occurred in June 2008 during a period of flooding in the Midwest. The peak streamflow measured at site number 7 on June 16, 2011, is 81 percent less than the peak streamflow measured during the 2008 flood. The highest streamflow ever recorded at site number 58 occurred during the 1993 flood. The peak streamflow measured on May 2, $2011\left(876,000 \mathrm{ft}^{3} / \mathrm{s}\right)$ is 12 percent less than the peak streamflow measured at site number 58 on August 7, 1993. In the lower MississippiAtchafalaya River Subbasin, streamflow measured during the 2011 flood exceeded streamflow measured during prior floods in the region. At site number 64, streamflow measured on May 19, 2011 (2.33 million $\left.\mathrm{ft}^{3} / \mathrm{s}\right)$ is 18 percent greater than the prior record streamflow of 1.96 million $\mathrm{ft}^{3} / \mathrm{s}$ measured during the 1973 flood (table 3). Similarly, streamflow measured at site

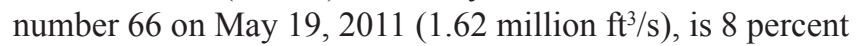
greater than the prior record streamflow of 1.498 million $\mathrm{ft}^{3} / \mathrm{s}$ measured on May 16, 1973 (table 3).

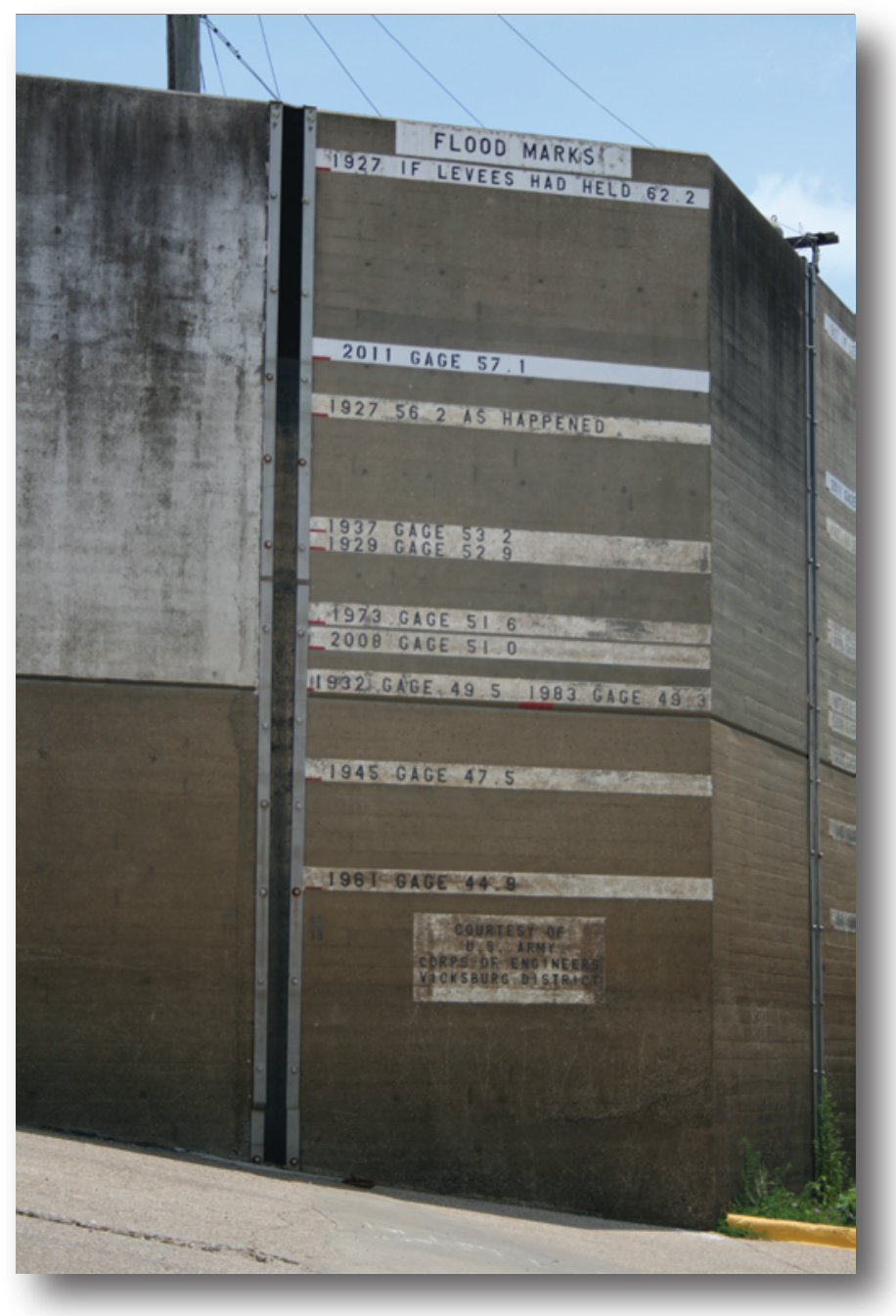

Figure 14. U.S. Army Corps of Engineers documents the height of all major floods of the Mississippi River on the levee wall at Vicksburg, Mississippi. The only mark higher than the stage measured on May 19, 2011, is that of the 1927 flood.

\section{Concentrations of Selected Water- Quality Constituents in the Subbasins during the 2011 Flood}

Concentrations of suspended sediment, nutrients, and atrazine varied among the four subbasins during the flood period. The maximum suspended-sediment concentration measured was $8,490 \mathrm{mg} / \mathrm{L}$ at a site in the Missouri River Subbasin, and the highest median suspended-sediment concentration $(450 \mathrm{mg} / \mathrm{L})$ was from the Missouri River Subbasin when compared to the three other subbasins (table 4). Median suspended-sediment concentrations in the Ohio River and the lower Mississippi-Atchafalaya River Subbasins were about one-half the median concentration of samples collected in the upper Mississippi River Subbasin.

Median concentrations of total nitrogen and nitrate were higher in the upper Mississippi River Subbasin, when compared to the three other subbasins (table 4). However, the highest concentration of total nitrogen and nitrate were measured in the Missouri River Subbasin. The maximum and highest median concentrations of total phosphorus were measured within the Missouri River Subbasin (table 4). Although, the highest orthophosphate concentration measured was at a site in the Missouri River Subbasin $(1.94 \mathrm{mg} / \mathrm{L})$, the upper Mississippi River Subbasin had the highest median orthophosphate when compared to the other three subbasins. Median concentrations of the four nutrients were generally lower in the Ohio River and lower Mississippi-Atchafalaya River Subbasins.

The median concentration of atrazine measured was highest in the upper Mississippi River Subbasin (table 4). The maximum concentration of atrazine measured was $13.8 \mu \mathrm{g} / \mathrm{L}$ from a site within the Ohio River Subbasin. The lowest median concentration of atrazine was in the Missouri River Subbasin.

\section{Summary and Conclusions}

The high streamflow associated with the flooding of 2011 in the Mississippi River Basin from April through July forced the simultaneous opening of three major flood-control structures for the first time in history in the lower MississippiAtchafalaya River Subbasin, and the additional regulation of water released from dams within the Missouri River and Ohio River Subbasins in order to manage the large amount of water moving through the system. Peak streamflow was measured at the USGS streamflow-monitoring stations at the Ohio River at Metropolis and the Mississippi River at Vicksburg and at the U.S. Army Corps of Engineers streamflow-monitoring station at the Mississippi River at Tarbert Landing. However, the 1952 flood moved a larger volume of water in the Missouri River Subbasin than was moved in the subbasin during the 2011 flood. Historical peak stages were measured 
Table 4. Concentrations of selected constituents measured in each of the four subbasins during the 2011 Mississippi River flood, April through July.

[mg/L, milligrams per liter; $\mu \mathrm{g} / \mathrm{L}$, microgram per liter]

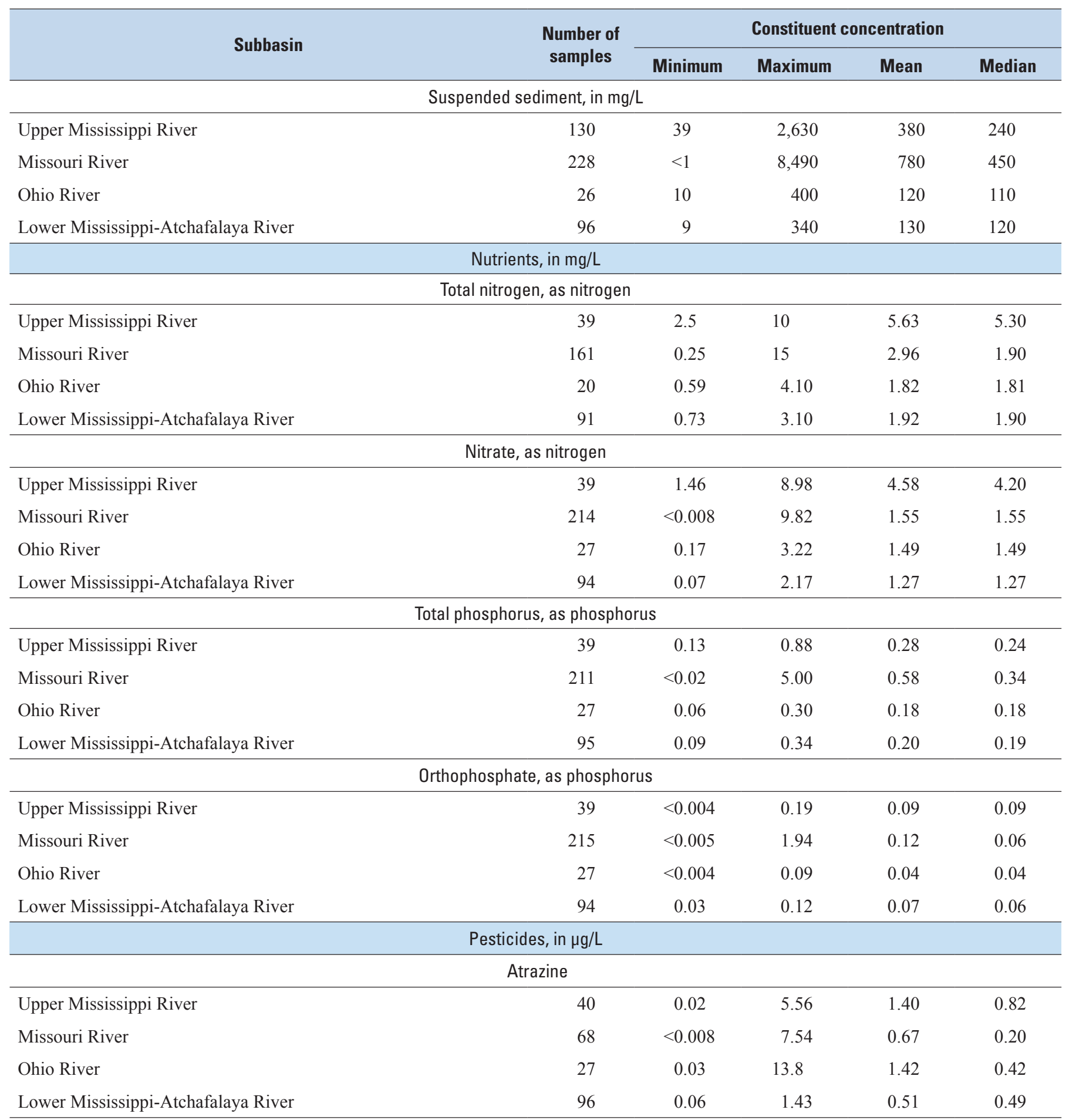


during the 2011 flood at the Mississippi River at Thebes, Illinois, and the Mississippi River at Vicksburg, Mississippi, USGS streamflow-monitoring stations. Higher stages were observed during the 1993 flood in portions of the Missouri River Subbasin and in the upper Mississippi River Subbasin than during the 2011 flood. Record rainfall in the Ohio River Subbasin was the primary contributor to streamflow in the lower Mississippi-Atchafalaya River Subbasin during the months of March, April, and May 2011. Record melting of snowpack in late May in the Missouri River Subbasin and above-normal precipitation from May through July in the upper Mississippi River Subbasin contributed to the majority of streamflow in the lower Mississippi-Atchafalaya River Subbasin during June and July.

To characterize water-quality during the flood, surface-water samples were collected at weekly to monthly intervals from 69 water-quality stations and 3 flood-control structures. During the 2011 flood, most of the sampled sites remained above flood stage for $2 \frac{1}{2}$ to 3 months, and instantaneous streamflow measurements at the time of sample collection were higher than historical median streamflow measurements at the time of corresponding water-quality sample collection. The Ohio River Subbasin is more urban and forested in land use, whereas the Missouri River Subbasin and upper Mississippi River Subbasin are primarily agricultural, with some rangeland. The timing and contribution of the streamflow from the two different source areas are important in determining which chemicals and other contaminants enter the lower Mississippi-Atchafalaya River Subbasin through overland runoff or water receding from inundated lands.

\section{References Cited}

Anderson, Bob, 2011, Operation watershed: Floodfight 2011: Inland Port, v. 3, no. 3, 24 p.

Camillo, C.A., 2012, Divine providence: The 2011 flood in the Mississippi River and Tributaries Project: Mississippi River Commission, $312 \mathrm{p}$.

Chin, E.H., Skelton, John, and Guy, H.P., 1975, The 1973 Mississippi River Basin flood: Compilation and analyses of meteorologic, streamflow, and sediment data: U.S. Geological Survey Professional Paper 937, 137 p.

Coupe, R.H. and Goolsby, D.A., 1999, Monitoring the water quality of the nation's large river: Mississippi River Basin NASQAN program: U.S. Geological Survey Fact Sheet FS-055-99, 6 p.

Fishman, M.J. and Friedman, L.C., eds., 1989, Methods for determination of inorganic substances in water and fluvial sediments: U.S. Geological Survey Techniques of WaterResources Investigations, book 5, chap. A1, 545 p.
Guy, H.P., 1969, Laboratory theory and methods for sediment analysis: U.S. Geological Survey Techniques of WaterResources Investigations, book 5, chap. C1.

Homer, Collin, Dewitz, Jon, Fry, Joyce, Coan, Michael, Hossain, Nazmul, Larson, Charles, Herold, Nate, McKerrow, Alexa, VanDriel J.N., and Wickham, James, 2007, Completion of the 2001 National Land Cover Database for the conterminous United States: Photogrammetric Engineering and Remote Sensing, v. 73, no. 4, p. 337-341.

Horowitz, A.J., 2010, A quarter century of declining suspended sediment fluxes in the Mississippi River and the effect of the 1993 flood: Hydrological Processes, v. 24, p. 13-34.

Meade, R.H., ed., 1995, Contaminants in the Mississippi River, 1987-1992: U.S. Geological Survey Circular 1133, $140 \mathrm{p}$.

Mississippi River Commission, 2008, The Mississippi River \& Tributaries Project: Designing the project flood: Mississippi River Commission Information Paper, 7 p.

Mossa, Joann, 1996, Sediment dynamics in the lowermost Mississippi River: Engineering Geology, v. 45, p. 457-479.

National Climatic Data Center, 2008, 2008 Midwestern U.S. floods: National Oceanic and Atmospheric Administration Special Reports, accessed June 28, 2011, at $h t t p: / / w w w$. ncdc.noaa.gov/special-reports/2008-floods.html.

Olson, S.A., and Norris, J.M., 2007, U.S. Geological Survey streamgaging from the National Streamflow Information Program: U.S. Geological Survey Fact Sheet 2005-3131, $4 \mathrm{p}$.

Parrett, Charles, Melcher, N.B., and James, Jr., R.W., 1993, Flood discharges in the Upper Mississippi River Basin, 1993: U.S. Geological Survey Circular 1120-A, 14 p.

Rantz, S.E., 1982, Measurement and computation of streamflow: volume 1. Measurement of stage and discharge and volume 2. Computation of discharge: U.S. Geological Survey Water Supply Paper 2175, 681 p.

Schneider, Kim, 2011, Laying the groundwork: U.S. Army Corps of Engineers Our Mississippi, 12 p.

Stone, Clifton, [n.d], Missouri River, The Natural Source, Northern State University, accessed June 14, 2012, at http:// www3.northern.edu/natsource/HABITATS/Missiol.htm.

U.S. Army Corps of Engineers, 2006, Missouri River mainstem reservoir system master water control manual, Missouri River Basin: U.S. Army Corps of Engineers Omaha District accessed June 14, 2012, at http://digitalcommons. unl.edu/cgi/viewcontent.cgi article $=1070 \&$ context $=u$ sarm yceomaha. 
U.S. Army Corps of Engineers, 2009, Ohio River Basin Comprehensive Reconnaissance Report: U.S. Army Corps of Engineers Pittsburg-Nashville-Louisville-Huntington-Great Lakes and Ohio River Division accessed June 14, 2012, at http://www.ohioriverbasin.org/pdfs/ ORBStudy.pdf.

U.S. Army Corps of Engineers, 2011a, Birds Point New Madrid Floodway map: Accessed February 18, 2013, at http://www.mvm.usace.army.mil/publicaffairs/News/press releases/bpnm/BPNM_Map.pdf.

U.S. Army Corps of Engineers, 2011b, Morganza Floodway travel times: EGIS Map ID no. 11-051-019, accessed February 18, 2013, at http://www.mvm.usace.army.mil/eng/edsd/ software/egisgateway.asp.

U.S. Army Corps of Engineers, 2012a, Birds Point-New Madrid Floodway Information Sheet: U.S. Army Corps of Engineers Memphis District: Accessed December 5, 2012,

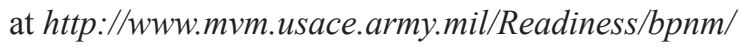
bpnminfo.asp.

U.S. Army Corps of Engineers, 2012b, Missouri River mainstem reservoir system summary of actual 2011 regulation, Missouri River Basin: U.S. Army Corps of Engineers Northwestern Division Report, accessed August 2012 at $h t t p: / / w w w . n w d-m r / u s a c e . a r m y . m i l / r c c / r e p o r t s / p d f s /$ rcc2011summary.pdf.

U.S. Department of the Interior, [n.d], National Atlas of the United States: Accessed on March 5, 2003, at http:// nationalatlas.gov.

U.S. Environmental Protection Agency, 1986, Test methods for evaluating solid water, physical/chemical methods (3d ed): SW-846 (various updates) (Also available at $h t t p: / /$ www.epa.gov/osw/hazard/testmethods/sw846/index.htm.)
U.S. Environmental Protection Agency, 1999, Method 1664, Revision A: $n$-hexane extractable material (HEM; oil and grease) and silica gel treated $n$-hexane extractable material (SGT-HEM; non-polar material) by extraction and gravimetry: EPA -821-R-98-002, 28 p.

U.S. Geological Survey, 2011, National Water Information System (NWISWeb): U.S. Geological Survey database, accessed January 31, 2013, at http://waterdata.usgs.gov/ $n w i s / s w$.

U.S. Geological Survey, 2012a, Water-resources data for the United States, Water Year 2011: U.S. Geological Survey Water-Data Report WDR-US-2011, site 0661000 and site 06486000, accessed January 31, 2013, at http://wdr.usgs. gov/wy2011/pdfs/0661000.2011.pdf and http://wdr.usgs.gov/ wy2011/pdfs/06486000.2011.pdf.

U.S. Geological Survey, 2012b, Water-resources data for the United States, Water Year 2011: U.S. Geological Survey Water-Data Report WDR-US-2011, site 06818000 , accessed January 31, 2013, at http://wdr.usgs.gov/wy2011/ $p d f s / 06818000.2011 . p d f$.

U.S. Geological Survey, variously dated, National field manual for the collection of water-quality data: U.S. Geological Survey Techniques of Water-Resources Investigations, book 9, chapters A1-A9. (Also available online at http://water.usgs.gov/owq/FieldManual/.)

Vining, K.C., Chase, K.J., and Loss, G.R., 2013, General weather conditions and precipitation contributing to the 2011 flooding in the Mississippi River and Red River of the North Basins, December 2010 through July 2011: U.S. Geological Survey Professional Paper 1798-B.

Welch, H.L., Aulenbach, B.T., and Coupe, R.H., 2012, Water quality in the lower Mississippi-Atchafalaya River Basin during the 2011 flood, April through July: U.S. Army Corps of Engineers retrospective on the 2011 flood. 



\section{Appendixes}

Appendixes 1-8 are available for download at $h t t p: / / p u b s . u s g s . g o v / o f / 2013 / 1106 /$ in the following formats:

1. Relative percent difference between environmental and replicate samples collected during the 2011 Mississippi River flood, April through July.

...MS Excel

2. Field parameters and inorganic data collected during the 2011 Mississippi River flood, April through July MS Excel

3. Suspended sediment, turbidity, and particle size data collected during the 2011 Mississippi River flood, April through July.... MS Excel

4. Nutrient concentration data collected during the 2011 Mississippi River flood, April through July MS Excel

5. Concentrations of detected pesticides in samples collected during the 2011 Mississippi River flood, April through July. MS Excel

6. Pesticides analyzed for, but not detected in samples collected during the 2011 Mississippi River flood, April through July. MS Excel

7. Sediment data from the Morganza Floodway and Bonnet Carré Spillways collected during the 2011 Mississippi River flood, April through July..... MS Excel

8. Oil and gas data collected in the Atchafalaya River basin from May through June 2011 MS Excel 
Prepared by the Raleigh Publishing Service Center

For more information about this publication, contact:

Director, USGS Mississippi Water Science Center

308 S. Airport Rd

Jackson, MS 39208-6649

(601) 933-2900

Or visit the USGS home page at:

http://ms.water.usgs.gov/

USGS Publishing Service Center staff:

Mike Deacon, Editor

Kim Swidarski, Illustrations and layout 


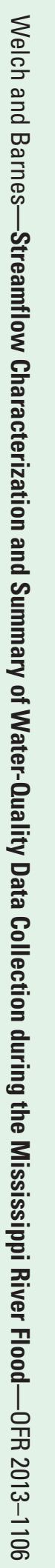

